\title{
Expression patterns and the prognostic value of the EMILIN/Multimerin family members in low-grade glioma
}

\author{
Yonghui Zhao ${ }^{\text {Corresp., } 1}{ }^{\text {, Xiang Zhang }}{ }^{1}$, Junchao Yao ${ }^{1}$, Zhibin Jin ${ }^{1}$, Chen Liu ${ }^{1}$ \\ ${ }^{1}$ Department of neurosurgery, Cangzhou central hospital, Cangzhou, hebei province, China \\ Corresponding Author: Yonghui Zhao \\ Email address: zhaoyonghui_1987@126.com
}

The management of Low-grade glioma (LGG) remains a challenge because of the infiltrating nature of the tumor, which cannot be cured by surgical resection. The EMILIN/Multimerins containing the $\mathrm{gClq}$ signature which were involved in many processes of tumor development. However, the expression of EMILIN/Multimerins in LGG and its prognostic value remains unclear. This study investigates the expression pattern, prognostic significance and function of EMILIN/Multimerins in LGG patients based on integrated bioinformatics analysis. The transcriptional levels and prognosis of EMILIN/Multimerins in LGG were analyzed by the ONCOMINE, GEPIA and UALCAN. The EMILIN/Multimerins' mutation, co-expression neighboring genes were analyzed via cBioProtal. TIMER and Metascape were used to reveal the potential mechanism of EMILIN/Multimerins in LGG. And we found that most EMILIN/Multimerins were overexpressed in LGG and share a clear association with immune cells. GEPIA confirmed that high levels of EMILIN/Multimerins were closely correlated with poor prognosis in LGG patients, except the MMRN2 in disease-free survival (DFS). The expression of EMILIN/Multimerins was related to different pathological grades. Potential mechanisms of different EMILIN/Multimerins in regulating LGG was revealed. Our findings showed that EMILIN/Multimerins might serve as novel prognostic biomarkers and possibly be a highpriority therapeutic target for LGG patients. 
1 Expression patterns and prognostic values of the 2 EMILIN/Multimerin family members in low-grade gliomas

3 Yonghui Zhao ${ }^{1}$, Xiang Zhang ${ }^{1}$, Junchao Yao ${ }^{1}$, Zhibin Jin ${ }^{1}$, Chen Liu ${ }^{1}$

4 1. Department of neurosurgery, Cangzhou central hospital, Cangzhou, Hebei 061000, People's

5 Republic of China

6 Corresponding Author; Yonghui Zhao;

7 Corresponding email address: zhaoyonghui_1987@126.com 
23 Abstract

24 Managing low-grade gliomas (LGG) remains a major medical challenge due to the infiltrating nature of the tumor and failure of surgical resection to eliminate the disease. EMILIN/Multimerins containing the $\mathrm{gClq}$ signature which are involved in many tumor processes. However, the expression and prognostic value of EMILIN/Multimerins in LGG remains unclear. This study used used integrated bioinformatics analysis to investigates the expression pattern, prognostic value and function of EMILIN/Multimerins in patients with LGG.

We analyzed the transcription levels and prognostic value EMILIN/Multimerins in LGG using the ONCOMINE, GEPIA (Gene Expression Profiling Interactive Analysis) and UALCAN databases. The mutation and co-expression rates of neighboring genes in EMILIN/Multimerins were studied using cBioPortal. TIMER and Metascape were used to reveal the potential function of EMILIN/Multimerins in LGG.

According to our analysis, most EMILIN/Multimerins were overexpressed in LGG and shared a clear association with immune cells. GEPIA analysis confirmed that high levels of EMILIN/Multimerins, not including MMRN2, were associated with a poor prognosis in diseasefree survival (DFS) of patients with LGG. Additionally, we discovered that EMILIN/Multimerins may regulate LGG and we found a correlation between their expression patterns and distinct pathological grades.

41 We found that EMILIN/Multimerins serve as possible prognostic biomarkers and high-priority therapeutic targets patients with LGG. 


\section{Introduction}

44 Low-grade gliomas (LGG), comprised of WHO grades II and III gliomas(Louis et al. 2007),

accounts for $15 \%-20 \%$ of all central nervous system glial tumors(Forst et al. 2014). Previous studies show LGG is highly heterogeneous in pathology, molecular features and prognosis(Burak Atci et al. 2019). Although LGG have a benign course with longer-term survival in comparison with glioblastoma(Brat et al. 2015), LGG cannot be cured entirely by conventional treatment, due to the frequent cancer recurrence and malignant progression which can turn into high grade glioma(Kumthekar et al. 2015). It is imperative for early LGG detection and precise prognosis that we screen for sensitive and reliable biomarkers.

The recently defined elastin microfibrillar interface protein(EMILIN) and Multimerin family is characterized by a $\mathrm{C}$-terminal $\mathrm{gClq}$ globular domain, containing five members: EMILIN1, EMILIN2, EMILIN3, MMRN1 and MMRN2(Colombatti et al. 2011; Schiavinato et al. 2012). These members have exerted a diverse range of function in the previous study(Capuano et al. 2019; Rabajdova et al. 2016; Schiavinato et al. 2016), which can affect cell growth, wound healing, angiogenesis, lymphangiogenesis and tumor microenvironment, etc. Notably, previous research has reported that high expression of EMILIN3 was confirmed to predict poor survival in LGG(Zeng et al. 2018). And, recent studies have confirmed that the appearance of Multimerin-2 and EMILIN-2 is significantly altered in gastric cancer patients(Andreuzzi et al. 2018) and EMILIN2 has a bidirectional role in tumor microenvironments(Mongiat et al. 2010). Although EMILIN/Multimerins act as promising biomarkers in tumor development, heir expression pattern, molecular function and prognostic value in LGG have not been investigated. 
We used bioinformatics analysis to investigate the expression pattern, molecular mechanism and prognostic value of EMILIN/Multimerins in patients with LGG. The expression of most EMILIN/Multimerins was significantly upregulated in patients with LGG. We found that a low expression of EMILIN/Multimerins predicted higher survival rates, establishing prognostic value. Additionally, we studied the potential for EMILIN/Multimerins to enhance molecular diagnosis and predict LGG prognosis.

\section{Methods}

\section{Oncomine analysis}

Oncomine analysis (Rhodes et al. 2004) was used to explore EMILIN/Multimerin expression levels in various cancer types. In the first search, we used the following keywords: "EMILIN1", "EMILIN2", "EMILIN3", "MMRN1" and "MMRN2", the primary filter for the analysis type was "Cancer vs Normal Analysis", and the chosen cancer type was "Brain and CNS Cancers". We set the following thresholds: $p$-value $=0.05$, fold change "All" and gene rank Top $10 \%$. To compare the expression of EMILIN/Multimerins in LGG subtypes and normal tissue, "EMILIN1" and "EMILIN2" were selected as keywords. "Diffuse Astrocytoma vs. Normal Analysis" was the chosen analysis type, and we set thresholds for $p$-value $=0.05$, fold change " 2 " and gene rank Top 10\%. Additionally, "EMILIN3", "MMRN1" and "MMRN2" were selected as keywords, and the analysis type and threshold were the same as the previous search (Diffuse Astrocytoma vs. Normal Analysis; $p$-value $=0.05$, fold change " 2 " and gene rank Top 10\%).

\section{UALCAN analysis}

Using the UALCAN database(Chandrashekar et al. 2017), we analyzed the expression profiles 
85

86

87

of EMILIN/Multimerin expression patterns in normal brain tissue and low-grade glioma samples. We established the correlation between expression levels of candidate genes and LGG tumor grades. The unique transcription expression of each tumor grade was compared using student's ttest, considering $p<0.01$ statically significant.

\section{GEPIA analysis}

We conducted GEPIA using the TCGA database(The Cancer Genome Atlas)(Tang et al. 2017) to investigate EMILIN/Multimerin expression levels on overall survival (OS) and disease-free survival (DFS) in patients with LGG. We tested our hypothesis using GEPIA's log-rank test and included the hazard ratio (HR) and 95\% confidence intervals (CI), considering $p$-values $<0.05$ statistically significant.

\section{TCGA and cBioPortal analysis}

According to TCGA dataset, we selected 530 pathology reports for further analysis (http://www.cbioportal.org/)(Gao et al. 2013). Kaplan-Meier plots displayed the relationship between EMILIN/Multimerin genetic mutations, OS and DFS in patients with LGG. A log-rank test was performed to identify different survival curves. We used cBioPortal's online instructions to calculate OncoPrint, cancer type summary and gene co-expression. Additionally, a network of EMILIN/Multimerins and neighboring genes was constructed using GeneMANIA software (www.genemania.org)(Warde-Farley et al. 2010).

\section{TIMER analysis}

Gene modules were used in TIMER (http://cistrome.shinyapps.io/timer)(Li et al. 2017) to analyze EMILIN expression levels in different cancer types. We studied the correlation between 
106 EMILIN and immune cells, including CD4+ $\mathrm{T}$ cells, $\mathrm{B}$ cells, CD8+ $\mathrm{T}$ cells, neutrophils, 107 macrophages and dendritic cells.

108 Metascape analysis

109 Metascape (http://metascape.org)(Tripathi et al. 2015) was used to conduct pathway and enrichment analysis of EMILIN family members and neighboring genes associated with EMILIN alterations. Gene Ontology (GO) terms (biological process, cellular component and molecular function categories) and Kyoto Encyclopedia of Genes and Genomes (KEGG) pathways were used in enrichment analysis. We only considered terms with a $p$-value $<0.01$, minimum count of three and enrichment factor $>1.5$ to be significant (Chen et al. 2019). The most statistically significant term within a cluster was chosen as the representative. A select subset of enriched terms was rendered as a network plot to further determine the relationship between terms; terms with a similarity $>0.3$ were connected by edges. Protein-protein interaction enrichment analysis was

performed using the following databases: BioGrid, InWeb_IM and OmniPath. Additionally, the

Molecular Complex Detection (MCODE) algorithm was applied to identify densely connected network components.

Results

\section{Expression analysis of EMILIN/Multimerin family members in patients with LGG}

To explore the prognostic and potential therapeutic value of varying EMILIN/Multimerin family members in LGG patients, the gene expression was analysed by ONCOMINE database. The expression of EMILIN/Multimerins in different types of cancers are shown in Figure 1 and

Table1. In the research of Lee Brain(Lee et al. 2006), Gutmann(Gutmann et al. 2002), TCGA, 
127 Sun(Sun et al. 2006), French(French et al. 2005), and Murat(Murat et al. 2008), we all found the 128 significantly over-expression of EMILIN1 in Brain and CNS Cancers in parallel to normal tissues. 129 In the datasets of Lee(Lee et al. 2006) and Bredel(Bredel et al. 2005), we observed highly increase 130 in EMILIN2 expression in Brain and CNS Cancers than normal tissues. The results from TCGA dataset and Beroukhim dataset(Beroukhim et al. 2007) indicated that EMILIN3 was significantly up-regulated in Brain and CNS Cancers than in normal tissues. Furthermore, the expression of MMRN1 was shown to be considerably higher in Brain and CNS Cancers than normal tissues in the Beroukhim dataset(Beroukhim et al. 2007). The result from Lee dataset(Lee et al. 2006) showed that MMRN2 was over-expressed in Brain and CNS Cancers, respectively.

In contrast with normal tissues, Beroukhim dataset(Beroukhim et al. 2007) and Bredel research(Bredel et al. 2005) was founded that significantly lower expressions of EMILIN3 in Brain and CNS Cancers. And Beroukhim dataset(Beroukhim et al. 2007) and TCGA dataset showed that there were lower in MMRN2 expression in Brain and CNS Cancers compared to normal tissues. members in Brain and CNS Cancers.

The expression levels of EMILIN/Multimerins in the Diffuse Astrocytoma and Anaplastic

Astrocytoma which were the subtypes of LGG.

Expression levels of EMILIN/Multimerins in diffuse astrocytoma and anaplastic 

subtypes. We found that EMILIN1 and EMILIN2 were overexpressed in diffuse astrocytoma compared to normal brain tissue. Additionally, there were higher expression levels of EMILIN3 and MMRN1 in anaplastic astrocytoma compared to normal brain tissue. However, the expression of MMRN2 was not markedly higher in anaplastic astrocytoma compared to normal brain tissue

(Figures 2A-E). Some datasets showed higher expression levels of EMILIN1, EMILIN2,

EMILIN3 and MMRN1 in LGG subtypes.

155

156

157

158

159

160

161

162

163

164

165

166

167

168

Association between the expression of EMILIN/Multimerins and tumor grades in patients with LGG

We used UALCAN to analyze the expression of EMILIN/Multimerins in LGG tumors and demonstrate the value of predicting survival rates. There was a high correlation between the expression of EMILIN/Multimerin family members and patient tumor grades (Figure 3A-E); patients with a more advanced tumor grade had a higher expression of EMILIN/Multimerins. These results suggest that the expression of EMILIN/Multimerin family members was significantly associated with tumor grades in patients with LGG.

\section{Association between the expression of EMILIN/Multimerins and prognosis of patients with}

\section{LGG}

We used GEPIA to analyze the role of EMILIN/Multimerin expression levels in predicting the prognosis of LGG. The expression of most EMILIN/Multimerin family members was significantly associated with LGG patient prognosis (Figure 4 and 5). There was a significant association between the lower expression of EMILIN/Multimerins and longer OS in patients with 
169

170

171

172

173

174

175

LGG (Figure 4A-E). A lower expression of EMILIN1, EMILIN2, EMILIN3 and MMRN1 was highly correlated with DFS (Figure 5A-E). However, MMRN2 expression levels were not correlated with DFS in patients with LGG.

Higher EMILIN/Multimerin expression levels were observed in poor LGG prognosis. We used UALCAN to demonstrate any significant associations between EMILIN/Multimerin expression levels and a patient's LGG tumor grade (Figure 6A-E). This association may be used as a biomarker for predicting LGG patient survival.

\section{The relationship between EMILIN/Multimerin expression levels and immune infiltration}

\section{levels in LGG}

Immunity is closely related to the occurrence and development of tumors. TIMER analysis was applied to the relationship between EMILIN/Multimerin expression levels and immune infiltration levels in LGG. EMILIN/Multimerin family members in LGG infiltrated similar immune cell profiles, showing a clear link to neutrophil, CD8+ T cell, dendritic cell, macrophage B cell and CD4+ T-cell populations (Figure 7 and Table 2). These findings suggest a correlation between EMILIN/Multimerin expression levels and immune infiltration levels in LGG.

\section{Exploring genetic alterations and neighboring genes of EMILIN/Multimerins in patients}

\section{with LGG}

The alteration frequency of EMILIN/Multimerin mutations in LGG was analyzed using cBioPortal and the results indicated five categories based on filtering (Figure 8A). The ratios of genetic alterations in EMILIN/Multimerins range from $0.4 \%$ to $1.4 \%$ for each member (EMILIN1 0.4\%, EMILIN2 1.4\%, EMILIN3 0.4\%, MMRN1 0.4\% and MMRN2 1.4\%; Figure 8B). 
190

191

192

193

194

195

196

197

198

199

200

201

202

203

204

205

206

207

208

209

210

Additionally, we analyzed genetic alterations in EMILIN/Multimerins and their association with

OS and DFS in patients with LGG. There was no discernable difference in OS and DFS cases with or without EMILIN/Multimerin alterations (Figure 8C and D). The fifty most frequently altered neighboring genes were used to construct a network using cBioportal. These findings indicated that A2M, ACTN1, ACTN2, ALB and ALDOA were closely associated with EMILIN/Multimerin alterations and functions (Figure 8E).

\section{Co-expression and interaction analyses of EMILIN/Multimerins in patients with LGG}

We performed bioinformatics analysis to explore the co-expression and interaction of EMILIN/Multimerins in patients with LGG. EMILIN1, EMILIN2 and EMILIN3 were positively correlated with each other. However, there was a negative relationship between EMILIN3 and MMRN2 (Figure 9A). Using GeneMANIA, we constructed an EMILIN/Multimerin network using the structure and function of neighboring genes. The results revealed twenty genes, including F5, TGFBI, EGFL7 and IL33, that were significantly associated with EMILIN/Multimerin family members (Figure 9B).

\section{Functional enrichment analysis of EMILIN/Multimerins in patients with LGG}

We used Metascape to analyze the functions of EMILIN/Multimerins and their neighboring genes. We performed pathway and process enrichment analysis on fifty neighboring genes (Figure 10A and Table 3). Additionally, we constructed a network of enriched terms; a lower p-value was associated with terms containing more genes (Figure 10B). We constructed a protein-protein interaction (PPI) network and MCODE components were identified in the gene list (Figure 10C). We analyzed the functional enrichment of the three most significant MCODE components (Figure 
211 10D).

212 Regulating LGG using cBioportal and co-expression analysis of

213 EMILIN/Multimerins

214 Using cBioportal, we performed co-expression analysis to predict the biological functions and 215 potential mechanisms of EMILIN/Multimerins. We selected five co-expressed genes (PHTA2, 216 CLCL1, FSTL1, IQGAP1 and MYL12A) from the resulting analysis that were significantly 217 associated with EMILIN/Multimerins. GEPIA's Kaplan-Meier curve was used to evaluate the function of five co-expressed genes and their impact on the survival of patients with LGG. Each gene was significantly related to the prognosis of LGG. (Figure 11-13)

\section{DISCUSSION}

EMILIN/Multimerins are a unique family of glycoproteins present in the extracellular matrix

(Colombatti et al. 2011). Previous research demonstrated the role of EMILIN/Multimerins in

regulating tumor growth progression (Andreuzzi et al. 2018; Rabajdova et al. 2016) including the association of EMILIN3 in LGG survival rates (Zeng et al. 2018). LGG is a chronic disease characterized by tumor migration, infiltration of the brain's connectome and recurrence after conventional treatment (Delgado-Lopez et al. 2017). However, we lack knowledge regarding the relationship between EMILIN/Multimerins and LGG. In this study, we explored the expression patterns, prognostic values and potential mechanisms of EMILIN/Multimerins in LGG.

EMILIN1, the most notable member of the EMILIN/Multimerin family, was overexpressed in many organs, including blood vessels, lymphatic vessels, connective tissues, cardiovascular 
232 include cell adhesion and migration in tumor growth (Capuano et al. 2018). Modica, TME et 233 al(Modica et al. 2017) founded that EMILIN1 can silences the RAS-ERK pathway via alpha4beta1 234 integrin, decreasing tumor cell growth. Wensheng Qiu et al(Qi et al. 2019) confirmed that 235 EMILIN1 regulates the expression of TSPAN9, creating an anti-tumor effect in gastric cancer. 236 However, there is no current research on the significance of EMILIN1 in patients with LGG. In 237 our study of EMILIN1, we observed significant links to tumor grades, overexpression in LGG and correlation between high-expression levels and poor OS and DFS.

In some solid tumors, such as gastric cancer, breast cancer, EMILIN2 can play essential functions in the tumor microenvironment, affecting tumor growth by directly binding epidermal growth factor receptor (EGFR) and lymphangiogenesis (Marastoni et al. 2014; Paulitti et al. 2018).

Paulitti, A et al(Paulitti et al. 2018) confirmed that EMILIN2 have causes defective vascularization due to impaired EGFR-dependent IL-8 production affecting tumor growth. Haage V et al.(Haage et al. 2019) used bioinformatics analysis to identify EMILIN2 as a gene candidate distinguishing microglia from peripheral monocytes/macrophages in healthy and diseased cells. The prognostic implications of EMILIN2 in LGG are not yet understood. In this study, our results indicated that

EMILIN2 had different expression levels in LGG, high-grade tumors and normal tissue. Survival curve analysis indicated that patients with LGG with a high expression of EMILIN2 were linked to poor OS and DFS.

EMILIN3 is a glycoprotein of the extracellular matrix missing the globular C1q domain 251 (Schiavinato et al. 2012). Zeng WJ et al.(Zeng et al. 2018) used bioinformatics analysis to study EMILIN3 as a prognostic gene in LGG, using genome-wide methylation and gene expression data. 
253 This study found a distinct EMILIN3 expression pattern in anaplastic astrocytoma; EMILIN3 was

254 also used to identify LGG tumor grades. Additionally, elevated levels of EMILIN3 were

255 significantly associated with shorter OS and DFS in patients with LGG.

256 MMRN1, a member of the EMILIN/Multimerin family, played a dynamic role in the

257 cytoarchitectural and adhesive changes accompanying platelet aggregation and clot formation

258 (Laszlo et al. 2015). Välk K et al.(Valk et al. 2010) found MMRN1 was involved in the

259 development of non-small-cell lung cancer through extracellular matrix formation, apoptosis,

260 blood vessel leakage and inflammation. The oncogenic role of MMRN1 is clear in several human

261 cancers. In this study, the expression of MMRN1 was positively correlated with tumor grades in

262 LGG; the overexpression of MMRN1 predicted poor prognosis in patients with LGG and indicated

263 anaplastic astrocytoma tissue when compared to normal tissue.

MMRN2, an extracellular matrix molecule specifically secreted by endothelial cells, played

an important role in the regulation of endothelial cell function, neo-angiogenesis and tumor

progression (Lorenzon et al. 2012). Noy, P J et al(Noy et al. 2015) found that MMRN2 binds to

the extracellular region of CLEC14A, inhibiting sprouting angiogenesis and tumor growth. In this

study, no significant difference in MMRN2 expression was observed between anaplastic

astrocytoma tissue and normal tissue. However, MMRN2 expression was positively correlated

with tumor grades in LGG. Overexpression of MMRN2 was related to lower OS in patients with

LGG, but was not correlated to DFS.

272

Previous studies (Sokratous et al. 2017) demonstrated that immune cell activation

accelerates tumor growth and progression, influencing tumor microenvironments. The key finding 
274 in this study indicated a high correlation between EMILIN/Multimerin expression and immune

275 infiltration levels in LGG. Our results show a positive relationship between EMILIN/Multimerin

276 expression levels and infiltration levels of B cells, CD4+ T cells, CD8+ T cells, neutrophils,

277 macrophages and dendritic cells. Additionally, a strong association was observed among MMRN1

278 and neutrophils and dendritic cells. Currently, studies illustrate that EMILIN/Multimerins display

279 many functions regulating tumor growth and lymph node metastases. During this study, we

performed co-expression and correlation analyses on EMILIN/Multimerins. We found that these

family members were strongly related to each other and the constructed PPI network.

To reveal the probable mechanism of EMILIN/Multimerins in LGG, we developed an

alteration frequency in anaplastic astrocytoma, astrocytoma, oligoastrocytoma, oligodendroglioma

and anaplastic oligoastrocytoma. We calculated the percentage of genetic alterations in

EMILIN/Multimerin family members using the TCGA dataset and found they varied from $0.4 \%$

to $1.4 \%$. The mutation analysis showed no significant prognostic value in OS and DFS in patients

with LGG, although the underlying mechanism is still unclear. We also constructed a network of

EMILIN/Multimerin family members and 50 neighboring genes. We selected five co-expressed

genes: PHTA2, CLCL1, FSTL1, IQGAP1 and MYL12A. We found that these genes significantly

correlated with EMILIN/Multimerins and predicted LGG patient prognosis. Due to a current lack

of evidence, additional experiments are needed to investigate the role of EMILIN/Multimerins in

LGG, including its potential mechanism in diagnostic and prognostic evaluation.

\section{Conclusions}


294

295

296

297

298

299

300

301

302

303

304

305

306

307

308

309

310

311

312

313

314

\section{1}

In conclusion, our study revealed that EMILIN/Multimerins were overexpressed at the mRNA

level and positively associated with LGG tumor grades. EMILIN/Multimerin expression levels

were systematically analyzed to evaluate their prognostic value in LGG and find effective strategies for diagnosis and treatment. These results illustrate the potential for EMILIN/Multimerins to serve as biomarkers in patients with LGG.

9

0

\section{AUTHOR CONTRIBUTION}

YH, Z designed this study and contributed substantially to the design of the search strategy, and

$\mathrm{YH}, \mathrm{Z}$ performed the analysis and interpreted the data, $\mathrm{YH}, \mathrm{Z}$ wrote the manuscript. ZX and JC, $\mathrm{Y}$ critically reviewed the manuscript. $\mathrm{YH}, \mathrm{Z}$ and $\mathrm{ZB}, \mathrm{J}$ participated in the data extraction and critically revised it. YH, Z and LC proofread the final version. All authors read and approved the final manuscript.

\section{ACKNOWLEDGEMENTS}

The authors received no funding.

\section{CONFLICTS of INTEREST}

The authors declare no competing financial interest. 
Andreuzzi E, Capuano A, Pellicani R, Poletto E, Doliana R, Maiero S, Fornasarig M, Magris R, Colombatti A, Cannizzaro R, Spessotto P, and Mongiat M. 2018. Loss of Multimerin-2 and EMILIN-2 Expression in Gastric Cancer Associate with Altered Angiogenesis. Int J Mol Sci 19. 10.3390/ijms19123983

Beroukhim R, Getz G, Nghiemphu L, Barretina J, Hsueh T, Linhart D, Vivanco I, Lee JC, Huang JH, Alexander S, Du J, Kau T, Thomas RK, Shah K, Soto H, Perner S, Prensner J, Debiasi RM, Demichelis F, Hatton C, Rubin MA, Garraway LA, Nelson SF, Liau L, Mischel PS, Cloughesy TF, Meyerson M, Golub TA, Lander ES, Mellinghoff IK, and Sellers WR. 2007. Assessing the significance of chromosomal aberrations in cancer: methodology and application to glioma. Proc Natl Acad Sci U S A 104:20007-20012. 10.1073/pnas.0710052104

Brat DJ, Verhaak RG, Aldape KD, Yung WK, Salama SR, Cooper LA, Rheinbay E, Miller CR, Vitucci M, Morozova O, Robertson AG, Noushmehr H, Laird PW, Cherniack AD, Akbani R, Huse JT, Ciriello G, Poisson LM, BarnholtzSloan JS, Berger MS, Brennan C, Colen RR, Colman H, Flanders AE, Giannini C, Grifford M, lavarone A, Jain R, Joseph I, Kim J, Kasaian K, Mikkelsen T, Murray BA, O'Neill BP, Pachter L, Parsons DW, Sougnez C, Sulman EP, Vandenberg SR, Van Meir EG, von Deimling A, Zhang H, Crain D, Lau K, Mallery D, Morris S, Paulauskis J, Penny R, Shelton T, Sherman M, Yena P, Black A, Bowen J, Dicostanzo K, Gastier-Foster J, Leraas KM, Lichtenberg TM, Pierson CR, Ramirez NC, Taylor C, Weaver S, Wise L, Zmuda E, Davidsen T, Demchok JA, Eley G, Ferguson ML, Hutter CM, Mills Shaw KR, Ozenberger BA, Sheth M, Sofia HJ, Tarnuzzer R, Wang Z, Yang L, Zenklusen JC, Ayala B, Baboud J, Chudamani S, Jensen MA, Liu J, Pihl T, Raman R, Wan Y, Wu Y, Ally A, Auman JT, Balasundaram M, Balu S, Baylin SB, Beroukhim R, Bootwalla MS, Bowlby R, Bristow CA, Brooks D, Butterfield Y, Carlsen R, Carter S, Chin L, Chu A, Chuah E, Cibulskis K, Clarke A, Coetzee SG, Dhalla N, Fennell T, Fisher S, Gabriel S, Getz G, Gibbs R, Guin R, Hadjipanayis A, Hayes DN, Hinoue T, Hoadley K, Holt RA, Hoyle AP, Jefferys SR, Jones S, Jones CD, Kucherlapati R, Lai PH, Lander E, Lee S, Lichtenstein L, Ma Y, Maglinte DT, Mahadeshwar HS, Marra MA, Mayo M, Meng S, Meyerson ML, Mieczkowski PA, Moore RA, 
Mose LE, Mungall AJ, Pantazi A, Parfenov M, Park PJ, Parker JS, Perou CM, Protopopov A, Ren X, Roach J, Sabedot TS, Schein J, Schumacher SE, Seidman JG, Seth S, Shen H, Simons JV, Sipahimalani P, Soloway MG, Song X, Sun H, Tabak B, Tam A, Tan D, Tang J, Thiessen N, Triche T, Jr., Van Den Berg DJ, Veluvolu U, Waring S, Weisenberger DJ, Wilkerson MD, Wong T, Wu J, Xi L, Xu AW, Yang L, Zack TI, Zhang J, Aksoy BA, Arachchi H, Benz C, Bernard B, Carlin D, Cho J, DiCara D, Frazer S, Fuller GN, Gao J, Gehlenborg N, Haussler D, Heiman DI, lype L, Jacobsen A, Ju Z, Katzman S, Kim H, Knijnenburg T, Kreisberg RB, Lawrence MS, Lee W, Leinonen K, Lin P, Ling S, Liu W, Liu Y, Liu Y, Lu Y, Mills G, Ng S, Noble MS, Paull E, Rao A, Reynolds S, Saksena G, Sanborn Z, Sander C, Schultz N, Senbabaoglu Y, Shen R, Shmulevich I, Sinha R, Stuart J, Sumer SO, Sun Y, Tasman N, Taylor BS, Voet D, Weinhold N, Weinstein JN, Yang D, Yoshihara K, Zheng S, Zhang W, Zou L, Abel T, Sadeghi S, Cohen ML, Eschbacher J, Hattab EM, Raghunathan A, Schniederjan MJ, Aziz D, Barnett G, Barrett W, Bigner DD, Boice L, Brewer C, Calatozzolo C, Campos B, Carlotti CG, Jr., Chan TA, Cuppini L, Curley E, Cuzzubbo S, Devine K, DiMeco F, Duell R, Elder JB, Fehrenbach A, Finocchiaro G, Friedman W, Fulop J, Gardner J, Hermes B, Herold-Mende C, Jungk C, Kendler A, Lehman NL, Lipp E, Liu O, Mandt R, McGraw M, McLendon R, McPherson C, Neder L, Nguyen P, Noss A, Nunziata R, Ostrom QT, Palmer C, Perin A, Pollo B, Potapov A, Potapova O, Rathmell WK, Rotin D, Scarpace L, Schilero C, Senecal K, Shimmel K, Shurkhay V, Sifri $S$, Singh R, Sloan AE, Smolenski K, Staugaitis SM, Steele R, Thorne L, Tirapelli DP, Unterberg A, Vallurupalli M, Wang Y, Warnick R, Williams F, Wolinsky Y, Bell S, Rosenberg M, Stewart C, Huang F, Grimsby $\mathrm{JL}$, Radenbaugh AJ, and Zhang J. 2015. Comprehensive, Integrative Genomic Analysis of Diffuse LowerGrade Gliomas. N Engl J Med 372:2481-2498. 10.1056/NEJMoa1402121

Bredel M, Bredel C, Juric D, Harsh GR, Vogel H, Recht LD, and Sikic BI. 2005. Functional network analysis reveals extended gliomagenesis pathway maps and three novel MYC-interacting genes in human gliomas. Cancer Res 65:8679-8689. 10.1158/0008-5472.Can-05-1204

Burak Atci I, Yilmaz H, and Samanci MY. 2019. The top 50 most-cited articles on low-grade glioma: a bibliometric analysis. Br J Neurosurg 33:171-175. 10.1080/02688697.2018.1549314

Capuano A, Fogolari F, Bucciotti F, Spessotto P, Nicolosi PA, Mucignat MT, Cervi M, Esposito G, Colombatti A, and Doliana R. 2018. The alpha4beta1/EMILIN1 interaction discloses a novel and unique integrin-ligand type of engagement. Matrix Biol 66:50-66. 10.1016/j.matbio.2017.10.001

Capuano A, Pivetta E, Baldissera F, Bosisio G, Wassermann B, Bucciotti F, Colombatti A, Sabatelli P, Doliana R, and Spessotto P. 2019. Integrin binding site within the gC1q domain orchestrates EMILIN-1-induced lymphangiogenesis. Matrix Biol 81:34-49. 10.1016/j.matbio.2018.10.006

Chandrashekar DS, Bashel B, Balasubramanya SAH, Creighton CJ, Ponce-Rodriguez I, Chakravarthi B, and Varambally S. 2017. UALCAN: A Portal for Facilitating Tumor Subgroup Gene Expression and Survival Analyses. Neoplasia 19:649-658. 10.1016/j.neo.2017.05.002

Chen SL, Qin ZY, Hu F, Wang Y, Dai YJ, and Liang Y. 2019. The Role of the HOXA Gene Family in Acute Myeloid Leukemia. Genes (Basel) 10. 10.3390/genes10080621

Colombatti A, Spessotto P, Doliana R, Mongiat M, Bressan GM, and Esposito G. 2011. The EMILIN/Multimerin family. Front Immunol 2:93. 10.3389/fimmu.2011.00093

Delgado-Lopez PD, Corrales-Garcia EM, Martino J, Lastra-Aras E, and Duenas-Polo MT. 2017. Diffuse low-grade glioma: a review on the new molecular classification, natural history and current management strategies. Clin Transl Oncol 19:931-944. 10.1007/s12094-017-1631-4

Forst DA, Nahed BV, Loeffler JS, and Batchelor TT. 2014. Low-grade gliomas. Oncologist 19:403-413. 
10.1634/theoncologist.2013-0345

French PJ, Swagemakers SM, Nagel JH, Kouwenhoven MC, Brouwer E, van der Spek P, Luider TM, Kros JM, van den Bent MJ, and Sillevis Smitt PA. 2005. Gene expression profiles associated with treatment response in oligodendrogliomas. Cancer Res 65:11335-11344. 10.1158/0008-5472.Can-05-1886

Gao J, Aksoy BA, Dogrusoz U, Dresdner G, Gross B, Sumer SO, Sun Y, Jacobsen A, Sinha R, Larsson E, Cerami E, Sander C, and Schultz N. 2013. Integrative analysis of complex cancer genomics and clinical profiles using the cBioPortal. Sci Signal 6:pl1. 10.1126/scisignal.2004088

Gutmann DH, Hedrick NM, Li J, Nagarajan R, Perry A, and Watson MA. 2002. Comparative gene expression profile analysis of neurofibromatosis 1-associated and sporadic pilocytic astrocytomas. Cancer Res 62:2085-2091.

Haage V, Semtner M, Vidal RO, Hernandez DP, Pong WW, Chen Z, Hambardzumyan D, Magrini V, Ly A, Walker J, Mardis E, Mertins P, Sauer S, Kettenmann H, and Gutmann DH. 2019. Comprehensive gene expression meta-analysis identifies signature genes that distinguish microglia from peripheral monocytes/macrophages in health and glioma. Acta Neuropathol Commun 7:20. 10.1186/s40478-0190665-y

Kumthekar P, Raizer J, and Singh S. 2015. Low-grade glioma. Cancer Treat Res 163:75-87. 10.1007/978-3-319-120485_5

Laszlo GS, Alonzo TA, Gudgeon CJ, Harrington KH, Gerbing RB, Wang YC, Ries RE, Raimondi SC, Hirsch BA, Gamis AS, Meshinchi S, and Walter RB. 2015. Multimerin-1 (MMRN1) as Novel Adverse Marker in Pediatric Acute Myeloid Leukemia: A Report from the Children's Oncology Group. Clin Cancer Res 21:3187-3195. 10.1158/1078-0432.Ccr-14-2684

Lee J, Kotliarova S, Kotliarov Y, Li A, Su Q, Donin NM, Pastorino S, Purow BW, Christopher N, Zhang W, Park JK, and Fine HA. 2006. Tumor stem cells derived from glioblastomas cultured in bFGF and EGF more closely mirror the phenotype and genotype of primary tumors than do serum-cultured cell lines. Cancer Cell 9:391-403. 10.1016/j.ccr.2006.03.030

Li T, Fan J, Wang B, Traugh N, Chen Q, Liu JS, Li B, and Liu XS. 2017. TIMER: A Web Server for Comprehensive Analysis of Tumor-Infiltrating Immune Cells. Cancer Res 77:e108-e110. 10.1158/0008-5472.Can-17-0307

Lorenzon E, Colladel R, Andreuzzi E, Marastoni S, Todaro F, Schiappacassi M, Ligresti G, Colombatti A, and Mongiat M. 2012. MULTIMERIN2 impairs tumor angiogenesis and growth by interfering with VEGF-A/VEGFR2 pathway. Oncogene 31:3136-3147. 10.1038/onc.2011.487

Louis DN, Ohgaki H, Wiestler OD, Cavenee WK, Burger PC, Jouvet A, Scheithauer BW, and Kleihues P. 2007. The 2007 WHO classification of tumours of the central nervous system. Acta Neuropathol 114:97-109. 10.1007/s00401-007-0243-4

Marastoni S, Andreuzzi E, Paulitti A, Colladel R, Pellicani R, Todaro F, Schiavinato A, Bonaldo P, Colombatti A, and Mongiat M. 2014. EMILIN2 down-modulates the Wnt signalling pathway and suppresses breast cancer cell growth and migration. J Pathol 232:391-404. 10.1002/path.4316

Modica TME, Maiorani O, Sartori G, Pivetta E, Doliana R, Capuano A, Colombatti A, and Spessotto P. 2017. The extracellular matrix protein EMILIN1 silences the RAS-ERK pathway via alpha4beta1 integrin and decreases tumor cell growth. Oncotarget 8:27034-27046. 10.18632/oncotarget.15067

Mongiat M, Marastoni S, Ligresti G, Lorenzon E, Schiappacassi M, Perris R, Frustaci S, and Colombatti A. 2010. The extracellular matrix glycoprotein elastin microfibril interface located protein 2: a dual role in the tumor microenvironment. Neoplasia 12:294-304. 10.1593/neo.91930

Peer) reviewing PDF | (2019:10:41856:2:0:NEW 30 Jan 2020) 
437

438

439

440

441

442

443

444

445

446

447

448

449

450

451

452

453

454

455

456

457

458

459

460

461

462

463

464

465

466

467

468

469

470

471

472

473

474

475

476

477

Murat A, Migliavacca E, Gorlia T, Lambiv WL, Shay T, Hamou MF, de Tribolet N, Regli L, Wick W, Kouwenhoven MC, Hainfellner JA, Heppner FL, Dietrich PY, Zimmer Y, Cairncross JG, Janzer RC, Domany E, Delorenzi M, Stupp $\mathrm{R}$, and Hegi ME. 2008. Stem cell-related "self-renewal" signature and high epidermal growth factor receptor expression associated with resistance to concomitant chemoradiotherapy in glioblastoma. J Clin Oncol 26:3015-3024. 10.1200/jco.2007.15.7164

Noy PJ, Lodhia P, Khan K, Zhuang X, Ward DG, Verissimo AR, Bacon A, and Bicknell R. 2015. Blocking CLEC14AMMRN2 binding inhibits sprouting angiogenesis and tumour growth. Oncogene 34:5821-5831. 10.1038/onc. 2015.34

Paulitti A, Andreuzzi E, Bizzotto D, Pellicani R, Tarticchio G, Marastoni S, Pastrello C, Jurisica I, Ligresti G, Bucciotti F, Doliana R, Colladel R, Braghetta P, Poletto E, Di Silvestre A, Bressan G, Colombatti A, Bonaldo P, and Mongiat M. 2018. The ablation of the matricellular protein EMILIN2 causes defective vascularization due to impaired EGFR-dependent IL-8 production affecting tumor growth. Oncogene 37:3399-3414. 10.1038/s41388-0170107-x

Qi Y, Lv J, Liu S, Sun L, Wang Y, Li H, Qi W, and Qiu W. 2019. TSPAN9 and EMILIN1 synergistically inhibit the migration and invasion of gastric cancer cells by increasing TSPAN9 expression. BMC Cancer 19:630. 10.1186/s12885019-5810-2

Rabajdova M, Urban P, Spakova I, Saksun L, Dudic R, Ostro A, Caprnda M, Kruzliak P, Adamek M, and Marekova M. 2016. The crucial role of emilin 1 gene expression during progression of tumor growth. J Cancer Res Clin Oncol 142:2397-2402. 10.1007/s00432-016-2226-0

Rhodes DR, Yu J, Shanker K, Deshpande N, Varambally R, Ghosh D, Barrette T, Pandey A, and Chinnaiyan AM. 2004. ONCOMINE: a cancer microarray database and integrated data-mining platform. Neoplasia 6:1-6. 10.1016/s1476-5586(04)80047-2

Schiavinato A, Becker AK, Zanetti M, Corallo D, Milanetto M, Bizzotto D, Bressan G, Guljelmovic M, Paulsson M, Wagener R, Braghetta P, and Bonaldo P. 2012. EMILIN-3, peculiar member of elastin microfibril interfacelocated protein (EMILIN) family, has distinct expression pattern, forms oligomeric assemblies, and serves as transforming growth factor beta (TGF-beta) antagonist. J Biol Chem 287:11498-11515. 10.1074/jbc.M111.303578

Schiavinato A, Keene DR, Wohl AP, Corallo D, Colombatti A, Wagener R, Paulsson M, Bonaldo P, and Sengle G. 2016. Targeting of EMILIN-1 and EMILIN-2 to Fibrillin Microfibrils Facilitates their Incorporation into the Extracellular Matrix. J Invest Dermatol 136:1150-1160. 10.1016/j.jid.2016.02.021

Sokratous G, Polyzoidis S, and Ashkan K. 2017. Immune infiltration of tumor microenvironment following immunotherapy for glioblastoma multiforme. Hum Vaccin Immunother 13:2575-2582. 10.1080/21645515.2017.1303582

Sun L, Hui AM, Su Q, Vortmeyer A, Kotliarov Y, Pastorino S, Passaniti A, Menon J, Walling J, Bailey R, Rosenblum M, Mikkelsen T, and Fine HA. 2006. Neuronal and glioma-derived stem cell factor induces angiogenesis within the brain. Cancer Cell 9:287-300. 10.1016/j.ccr.2006.03.003

Tang Z, Li C, Kang B, Gao G, Li C, and Zhang Z. 2017. GEPIA: a web server for cancer and normal gene expression profiling and interactive analyses. Nucleic Acids Res 45:W98-w102. 10.1093/nar/gkx247

Tripathi S, Pohl MO, Zhou Y, Rodriguez-Frandsen A, Wang G, Stein DA, Moulton HM, DeJesus P, Che J, Mulder LC, Yanguez E, Andenmatten D, Pache L, Manicassamy B, Albrecht RA, Gonzalez MG, Nguyen Q, Brass A, Elledge S, White M, Shapira S, Hacohen N, Karlas A, Meyer TF, Shales M, Gatorano A, Johnson JR, Jang G, Johnson

PeerJ reviewing PDF | (2019:10:41856:2:0:NEW 30 Jan 2020) 
478

479

480

481

482

483

484

485

486

487

488

489

490
T, Verschueren E, Sanders D, Krogan N, Shaw M, Konig R, Stertz S, Garcia-Sastre A, and Chanda SK. 2015. Meta- and Orthogonal Integration of Influenza "OMICs" Data Defines a Role for UBR4 in Virus Budding. Cell Host Microbe 18:723-735. 10.1016/j.chom.2015.11.002

Valk K, Vooder T, Kolde R, Reintam MA, Petzold C, Vilo J, and Metspalu A. 2010. Gene expression profiles of nonsmall cell lung cancer: survival prediction and new biomarkers. Oncology 79:283-292. 10.1159/000322116

Warde-Farley D, Donaldson SL, Comes O, Zuberi K, Badrawi R, Chao P, Franz M, Grouios C, Kazi F, Lopes CT, Maitland A, Mostafavi S, Montojo J, Shao Q, Wright G, Bader GD, and Morris Q. 2010. The GeneMANIA prediction server: biological network integration for gene prioritization and predicting gene function. Nucleic Acids Res 38:W214-220. 10.1093/nar/gkq537

Zeng WJ, Yang YL, Liu ZZ, Wen ZP, Chen YH, Hu XL, Cheng Q, Xiao J, Zhao J, and Chen XP. 2018. Integrative Analysis of DNA Methylation and Gene Expression Identify a Three-Gene Signature for Predicting Prognosis in LowerGrade Gliomas. Cell Physiol Biochem 47:428-439. 10.1159/000489954 


\section{Figure 1}

FIGURE 1 The expression levels of EMILIN/Multimerin family members in different types of cancers (ONCOMINE). The graph shows the numbers of datasets with statistically significant mRNA over-expression(red) or down-regulated expression(blue) of the target

The graph shows the numbers of datasets with statistically significant mRNA overexpression(red) or down-regulated expression(blue) of the target gene. The threshold was designed with the following parameters: $p$ value of 0.05 and fold change of All. 


\begin{tabular}{|c|c|c|c|c|c|c|c|c|c|c|}
\hline \multirow{2}{*}{$\begin{array}{l}\text { Analysis Type by Cancer } \\
\text { Bladder Cancer }\end{array}$} & \multicolumn{2}{|c|}{$\begin{array}{c}\text { Cancer } \\
\text { vs. } \\
\text { Normal } \\
\\
\text { EMILIN1 }\end{array}$} & \multicolumn{2}{|c|}{$\begin{array}{c}\text { Cancer } \\
\text { vs. } \\
\text { Normal } \\
\text { EMILIN2 }\end{array}$} & \multicolumn{2}{|c|}{$\begin{array}{l}\text { Cancer } \\
\text { vs. } \\
\text { Normal } \\
\\
\text { EMILIN3 }\end{array}$} & \multicolumn{2}{|c|}{$\begin{array}{c}\text { Cancer } \\
\text { vs. } \\
\text { Normal } \\
\text { MMRN1 }\end{array}$} & \multicolumn{2}{|c|}{$\begin{array}{c}\text { Cancer } \\
\text { vs. } \\
\text { Normal } \\
\text { MMRN2 }\end{array}$} \\
\hline & 1 & 5 & & & 3 & & & & & 3 \\
\hline Brain and CNS Cancer & 7 & & 2 & & 5 & 2 & 1 & & 1 & 5 \\
\hline Breast Cancer & 3 & 1 & 3 & 13 & 2 & 6 & & 13 & 1 & 8 \\
\hline Cervical Cancer & & 1 & & 2 & 1 & & & 1 & & 1 \\
\hline Colorectal Cancer & & 2 & 2 & 7 & 8 & 1 & & 16 & & 9 \\
\hline Esophageal Cancer & 3 & & 4 & & & 2 & 2 & 1 & 3 & 1 \\
\hline Gastric Cancer & 3 & & 4 & 1 & 9 & 1 & & 16 & & \\
\hline Head and Neck Cancer & 1 & 1 & 5 & & & & & 13 & 1 & 3 \\
\hline Kidney Cancer & & 5 & 2 & & 2 & & & 1 & & 5 \\
\hline Leukemia & 2 & 1 & 1 & 5 & & & 2 & & 1 & \\
\hline Liver Cancer & 3 & 1 & & & 2 & & & 7 & & \\
\hline Lung Cancer & 3 & 1 & & 2 & 2 & & & 10 & & 11 \\
\hline Lymphoma & 9 & & 10 & 2 & & & 1 & & 3 & 1 \\
\hline Melanoma & & & 1 & & 1 & & & 1 & & 1 \\
\hline Myeloma & & & & & & & & & & \\
\hline Other Cancer & 5 & 4 & 1 & 2 & 1 & & 1 & 5 & & 6 \\
\hline Ovarian Cancer & & 3 & 1 & 1 & & & & 1 & & 1 \\
\hline Pancreatic Cancer & 1 & & 1 & & 1 & & & 1 & & \\
\hline Prostate Cancer & & 6 & 2 & & 1 & 5 & 1 & 1 & & 1 \\
\hline Sarcoma & 7 & 1 & & & 2 & & & 2 & & 11 \\
\hline Significant Unique Analyses & 48 & 31 & 39 & 35 & 40 & 17 & 8 & 89 & 10 & 66 \\
\hline Total Unique Analyses & & & & & & & & 29 & & 59 \\
\hline
\end{tabular}

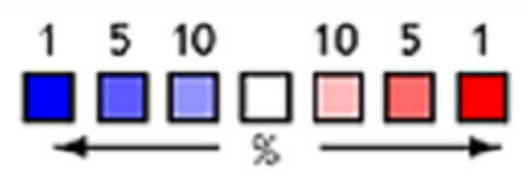




\section{Figure 2}

FIGURE 2 The expression of EMILIN/Multimerins in the subtypes of LGG and normal brain tissues(ONCOMINE).

A. The expression of EMILIN1 in diffuse astrocytoma and normal brain. B. The expression of EMILIN2 in diffuse astrocytoma and normal brain. C. The expression of EMILIN3 in anaplastic astrocytoma and normal brain. D. The expression of MMRN1 in anaplastic astrocytoma and normal brain. E. The expression of MMRN2 in anaplastic astrocytoma and normal brain. The $P$ value was set up at 0.05 and fold change was defined as 2 .
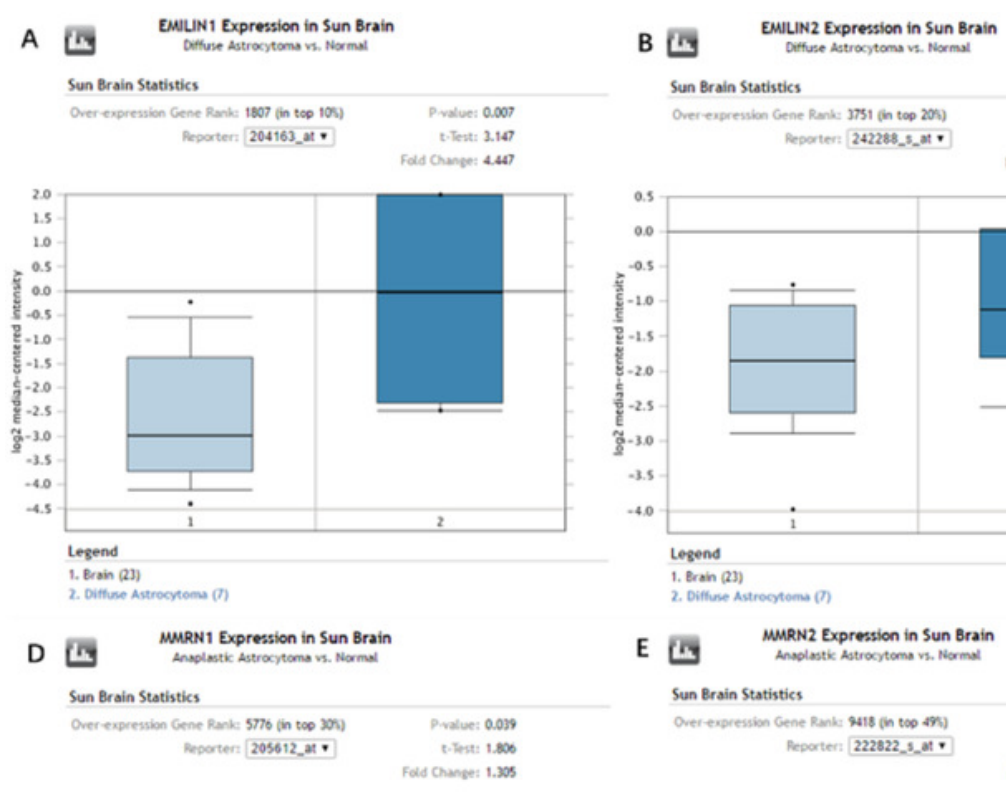

c L

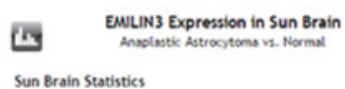
Sun Brain Statistics
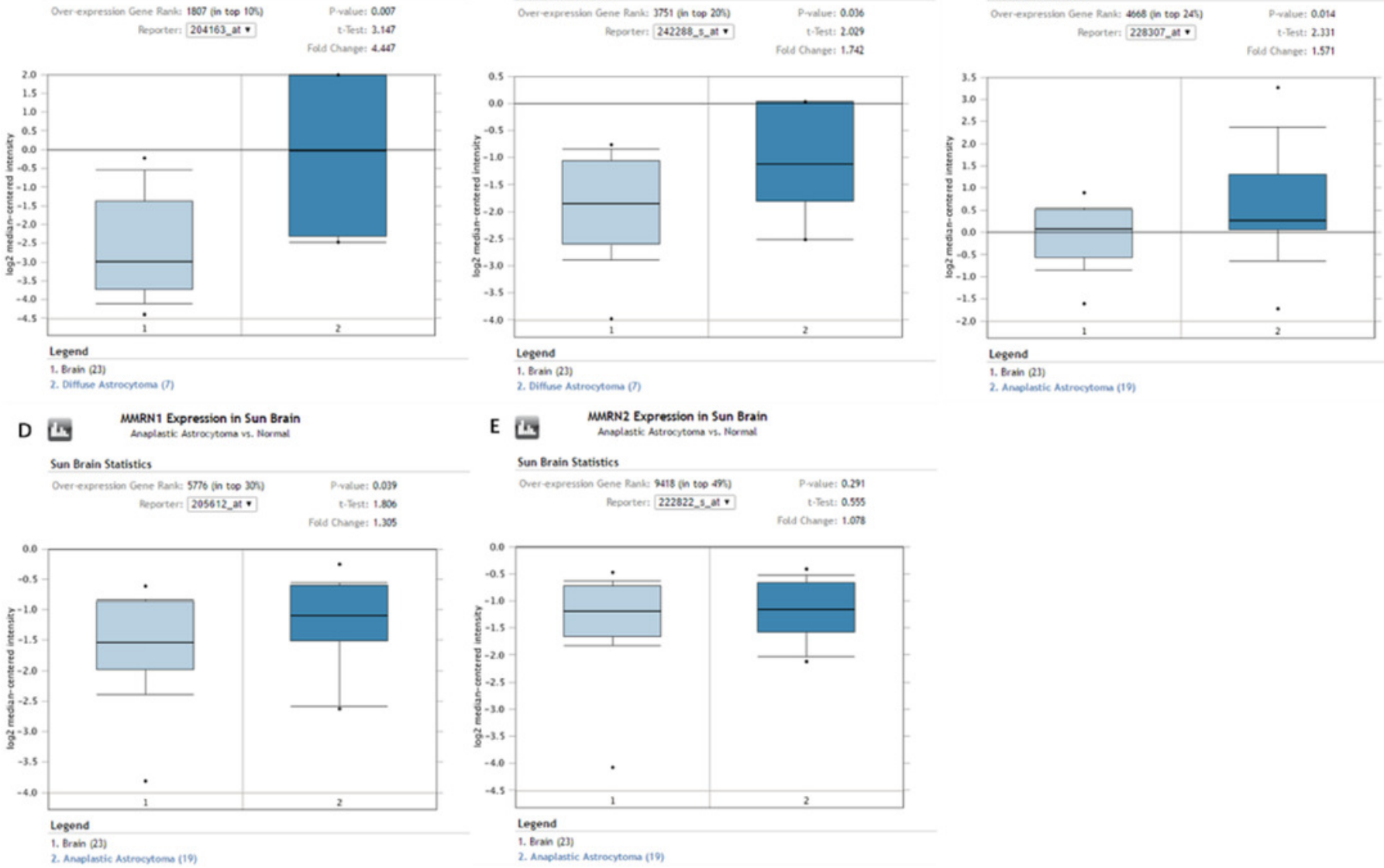

E MURN2 Expression in Sun Brain

Sun Brain Statistics

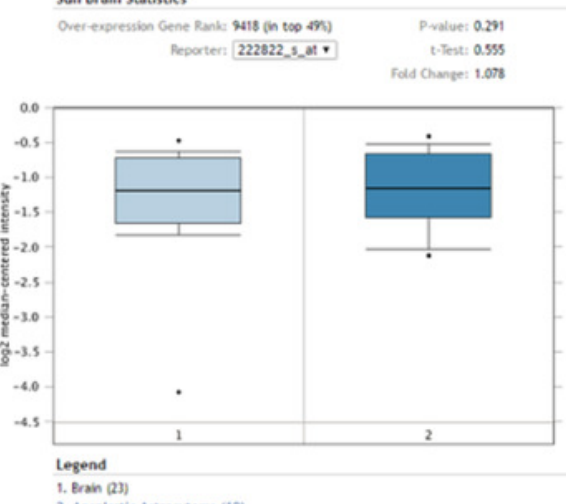

2. Aneolantis Adtrextoma (19) 


\section{Figure 3}

FIGURE 3 The expression of EMILIN/Multimerin family members in LGG based on tumor grade (UALCAN).

A. The expression of EMILIN1 was found to be overexpressed in grade 3 than grade 2 in LGG patients from the TCGA samples. B. The expression of EMILIN2 was found to be overexpressed in grade 3 than grade 2 in LGG patients from the TCGA samples. C. The expression of EMILIN3 was found to be overexpressed in grade 3 than grade 2 in LGG patients from the TCGA samples. D. The expression of MMRN1 was found to be overexpressed in grade 3 than grade 2 in LGG patients from the TCGA samples. E. The expression of MMRN2 was found to be overexpressed in grade 3 than grade 2 in LGG patients from the TCGA samples.
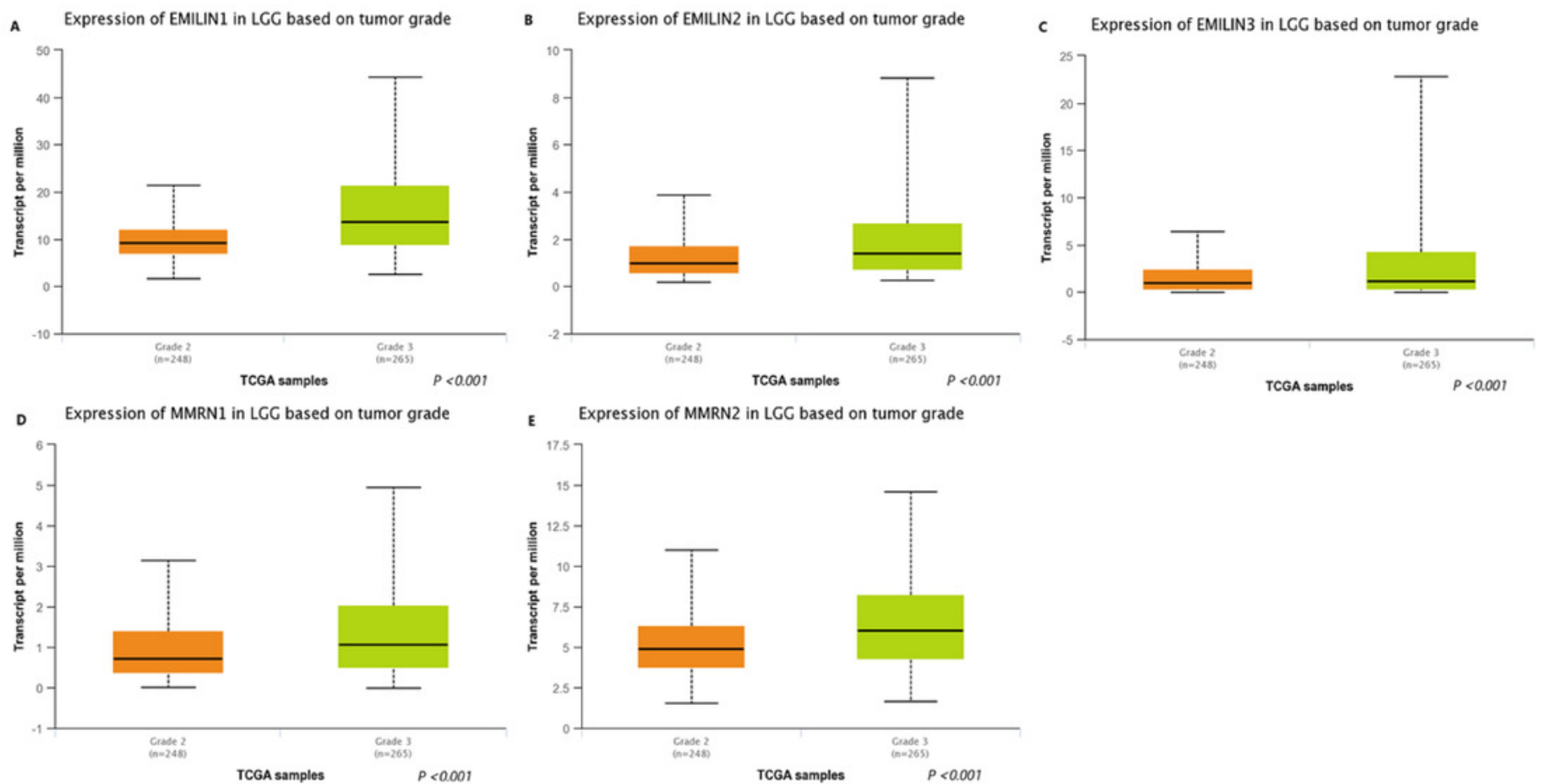
Figure 4

FIGURE 4 The overall survival of EMILIN family members in LGG.

A. Low expression level of EMILIN1 was associated with longer OS in LGG B. Low expression level of EMILIN2 was associated with longer OS in LGG C. Low expression level of EMILIN3 was associated with longer OS in LGG D. Low expression level of MMRN1 was associated with longer OS in LGG E. Low expression level of MMRN2 was associated with longer OS in LGG.
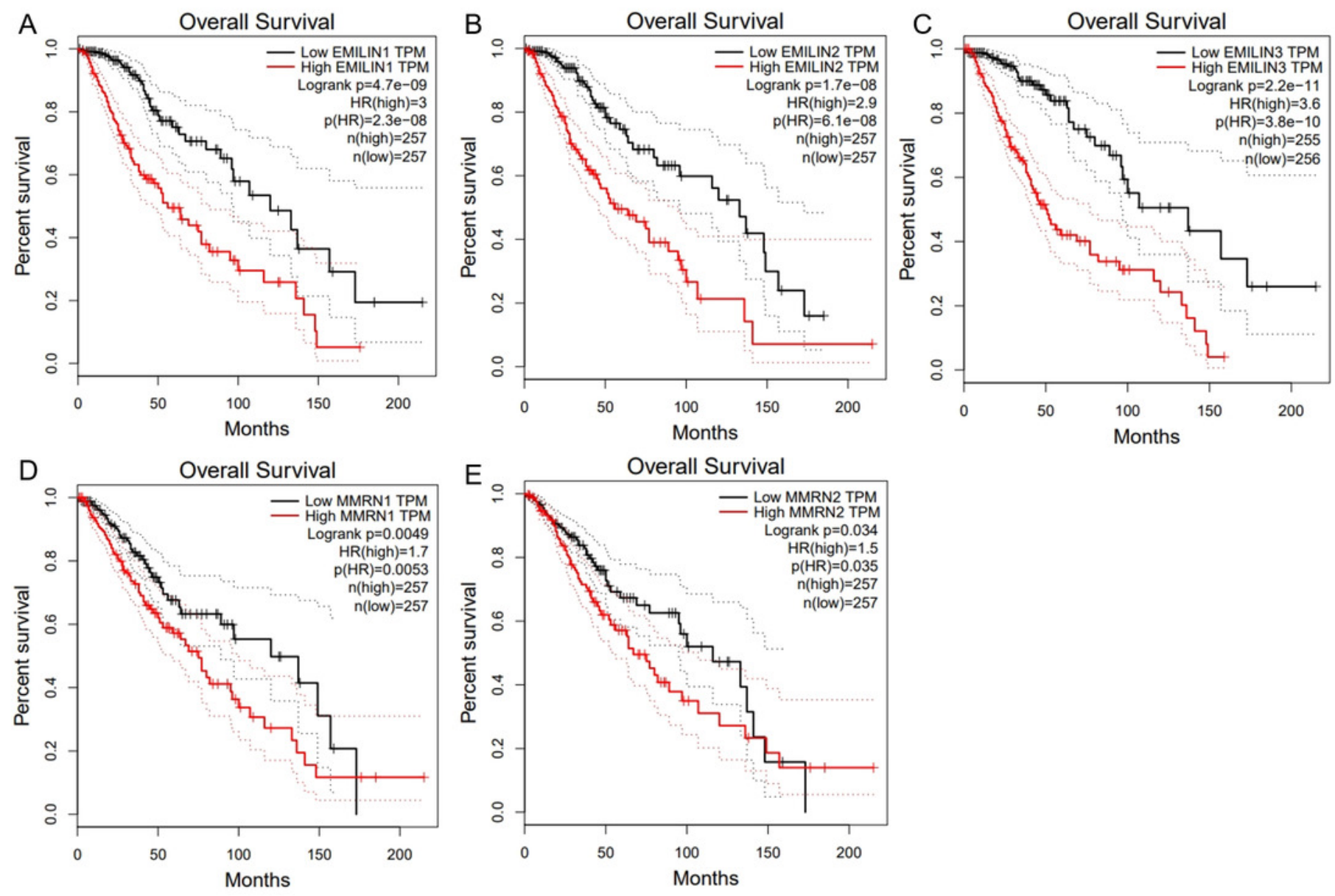
Figure 5

FIGURE 5 The Disease Free Survival (DFS)of EMILIN/Multimerin family members in LGG.

A. Low expression of EMILIN1 was associated with longer DFS in LGG B. Low expression of EMILIN2 was associated with longer DFS in LGG C. Low expression of EMILIN3 was associated with longer DFS in LGG D. Low expression of MMRN1 was associated with longer DFS in LGG E. The expression of MMRN2 was not significantly associated with DFS in LGG.
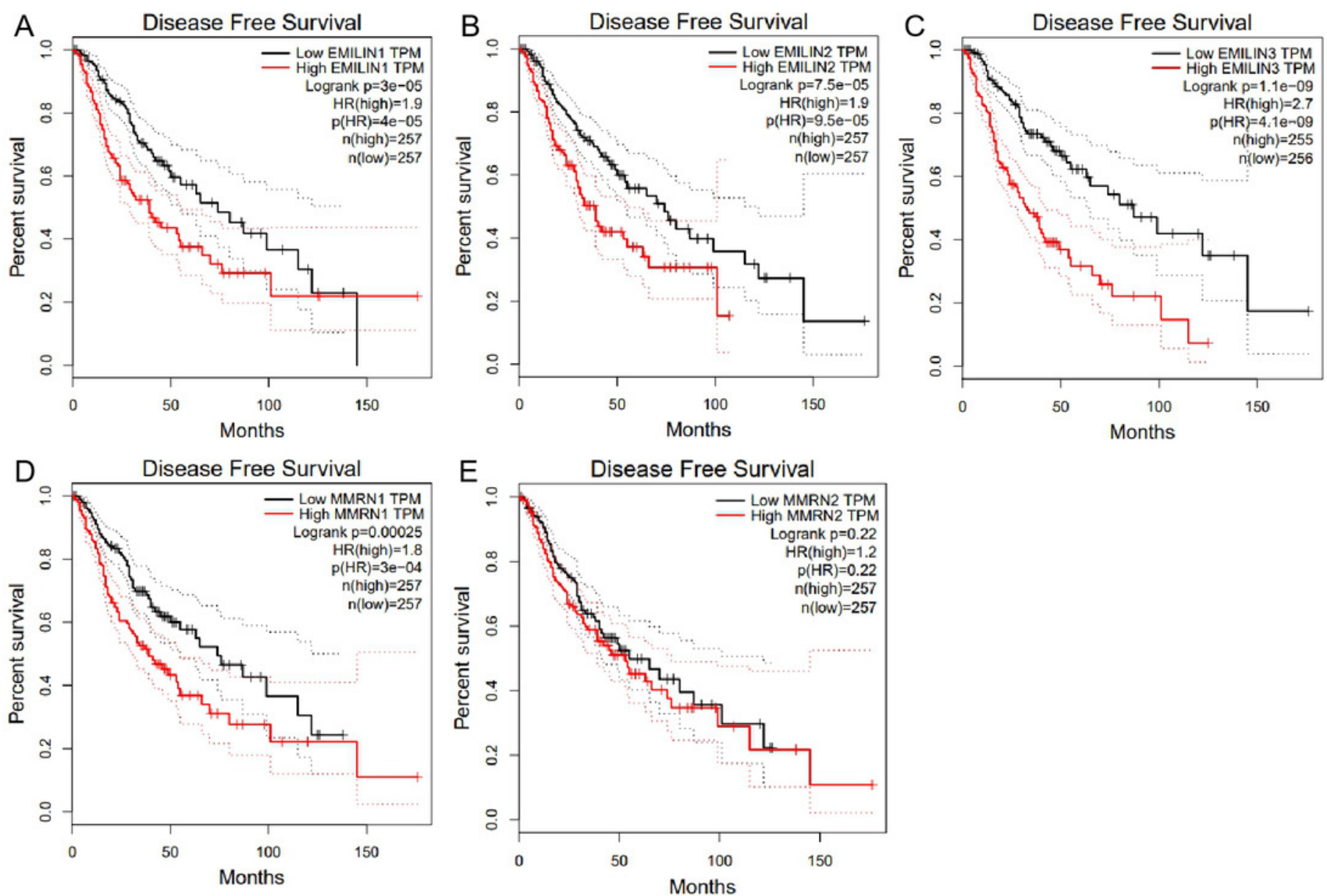


\section{Figure 6}

FIGURE 6 The effect of EMILIN/Multimerins expression level for the tumor grade on LGG patient survival.

A. The overexpression of EMILIN1 has the poorest prognosis in higher tumor grade of LGG patients. B. The overexpression of EMILIN2 has the poorest prognosis in higher tumor grade of LGG patients. C. The overexpression of EMILIN3 has the poorest prognosis in higher tumor grade of LGG patients. D. The overexpression of MMRN1 has the poorest prognosis in higher tumor grade of LGG patients. E. The overexpression of MMRN2 has the poorest prognosis in higher tumor grade of LGG patients.
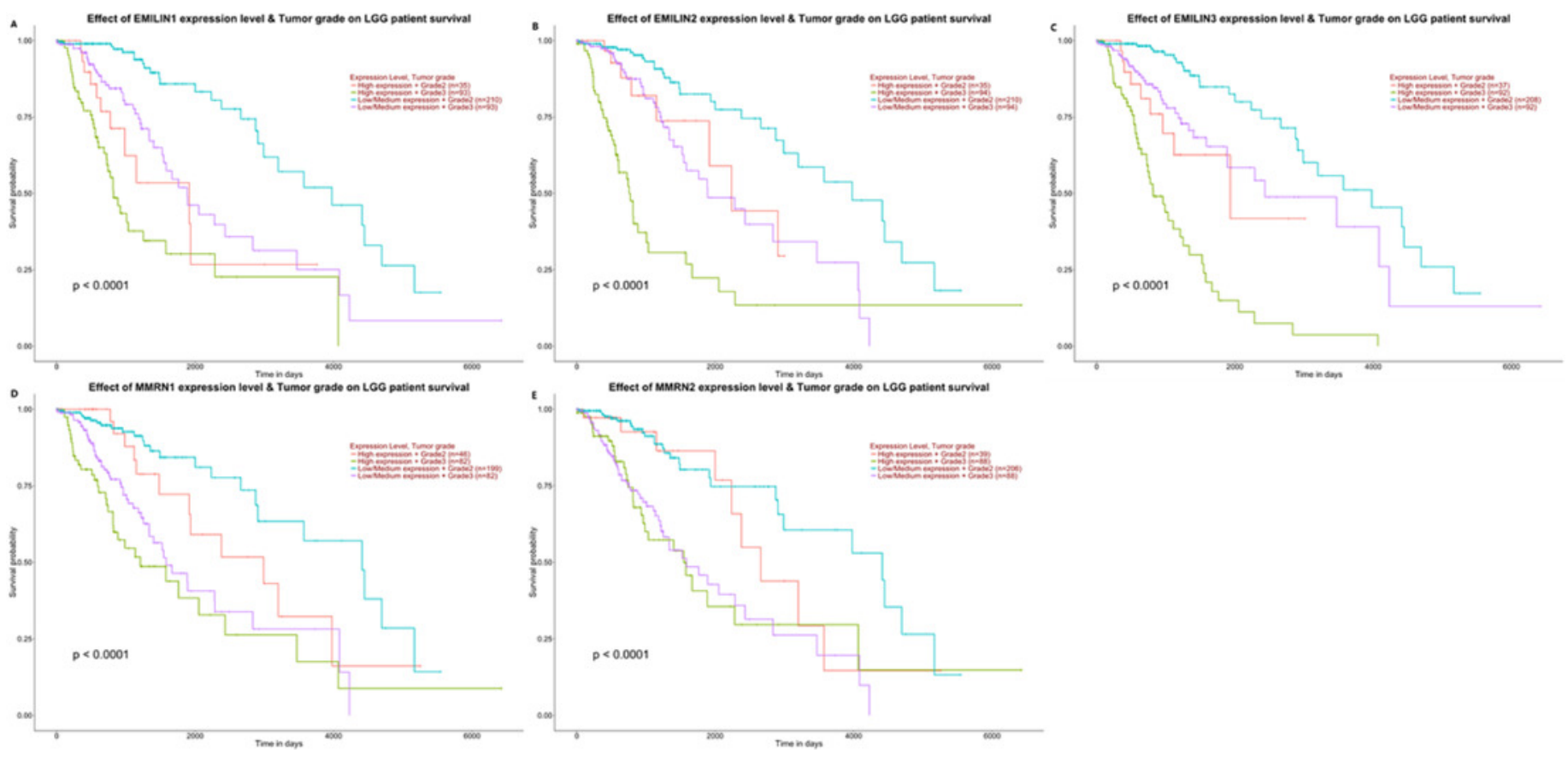


\section{Figure 7}

FIGURE 7 Immune cell landscape of LGG compare with EMILIN/Multimerins.

A-II illustrated that scatter plots were generated using the online tool TIMER to identify different profiles of immune cells associated with investigated genes. Each dot represents a single tumor sample.

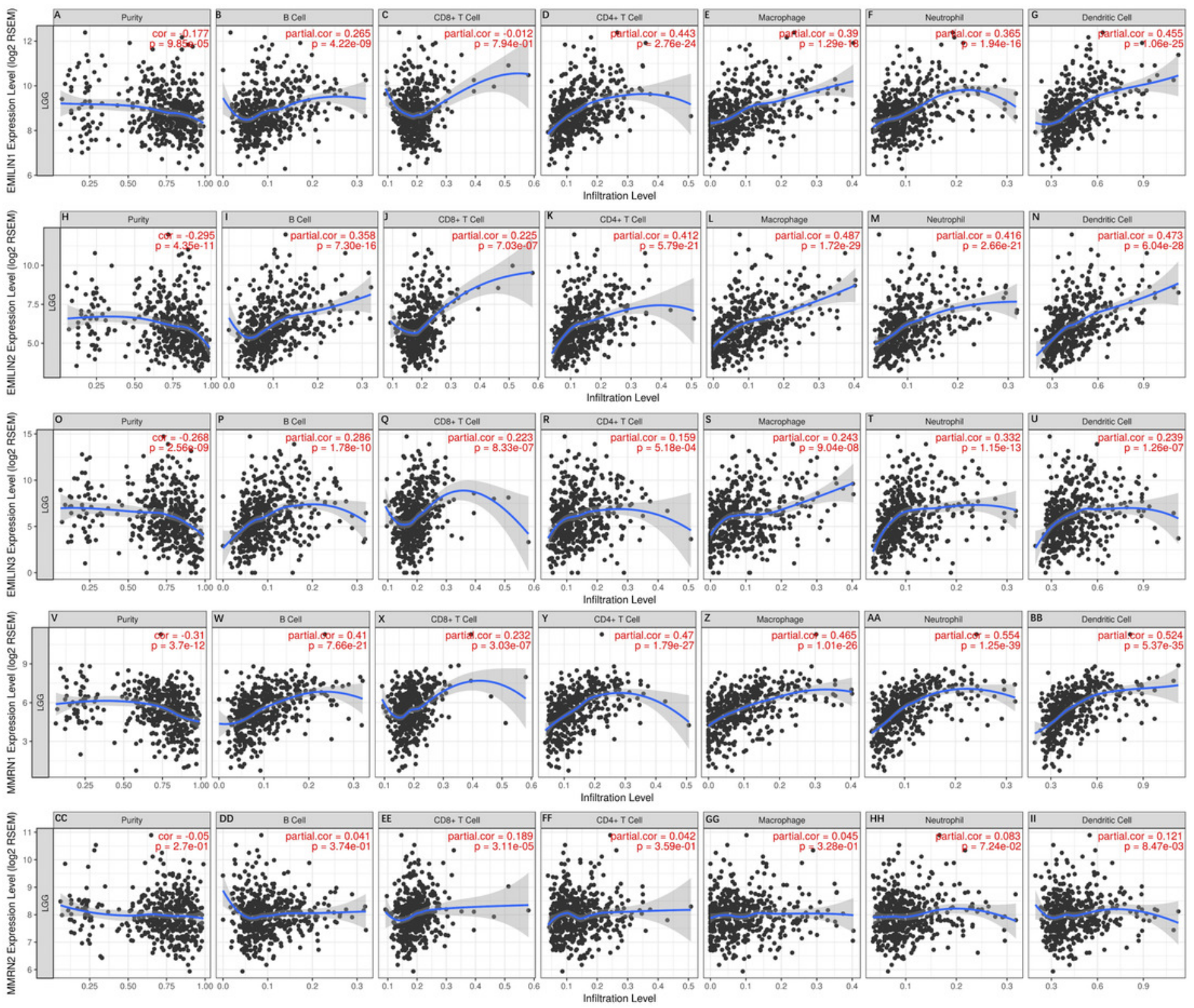




\section{Figure 8}

FIGURE 8 Alteration frequency of EMILIN/Multimerin family members and neighbor gene network in LGG (cBioPortal).

A. Summary of alterations in EMILIN family members B. OncoPrint visual summary of alteration on a query of EMILIN family members C. Kaplan-Meier plots comparing OS in cases with/without EMILIN family member gene alterations D. Kaplan-Meier plots comparing disease-free survival (DFS) in cases with/without EMILIN family member alterations E. Gene-gene interaction network among EMILIN family members and 50 most frequently altered neighboring genes.
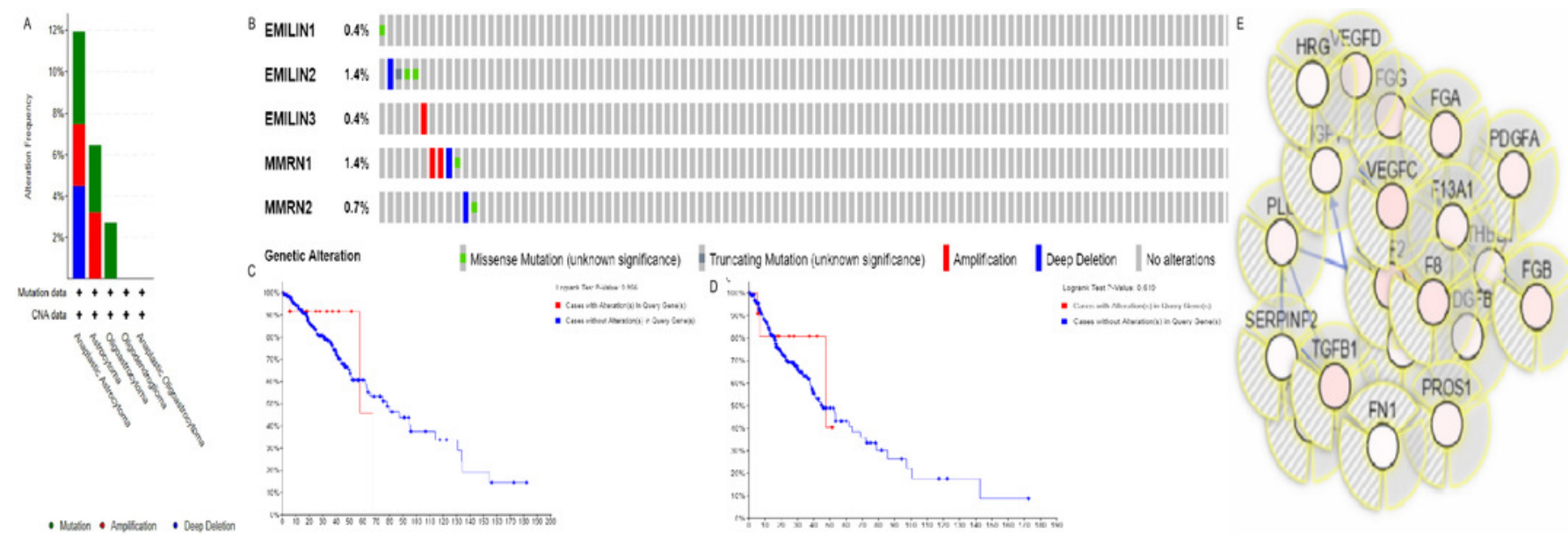


\section{Figure 9}

FIGURE 9 Co-expression and interaction analysis of EMILIN family members at the gene and protein levels in patients with LGG(cBioPortal and GeneMANIA).

A. Pearson correlation of EMILIN family members B. Protein-protein interaction network among EMILIN family members in the GeneMANIA dataset.

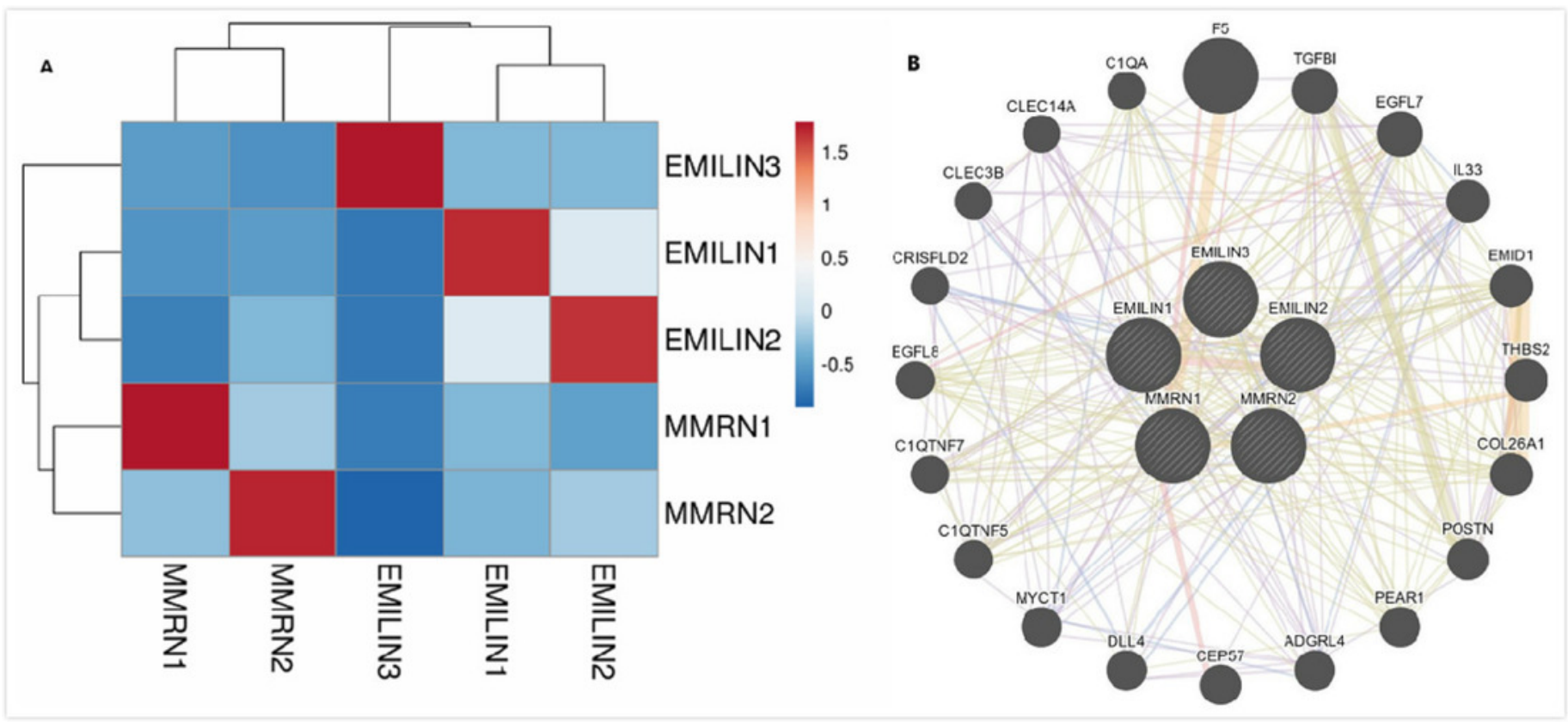


Figure 10

FIGURE 10 The enrichment analysis of EMILIN/Multimerin family members and neighboring genes in LGG (Metascape).

A. Heatmap of enriched terms across EMILIN family members and neighboring genes, colored by $p$-values $B$. Network of enriched terms colored by $p$-value, where terms containing more genes tend to have a more significant p-value C. Protein-protein interaction (PPI) network and three most significant MCODE components form the PPI network. D. Independent functional enrichment analysis of three MCODE components.
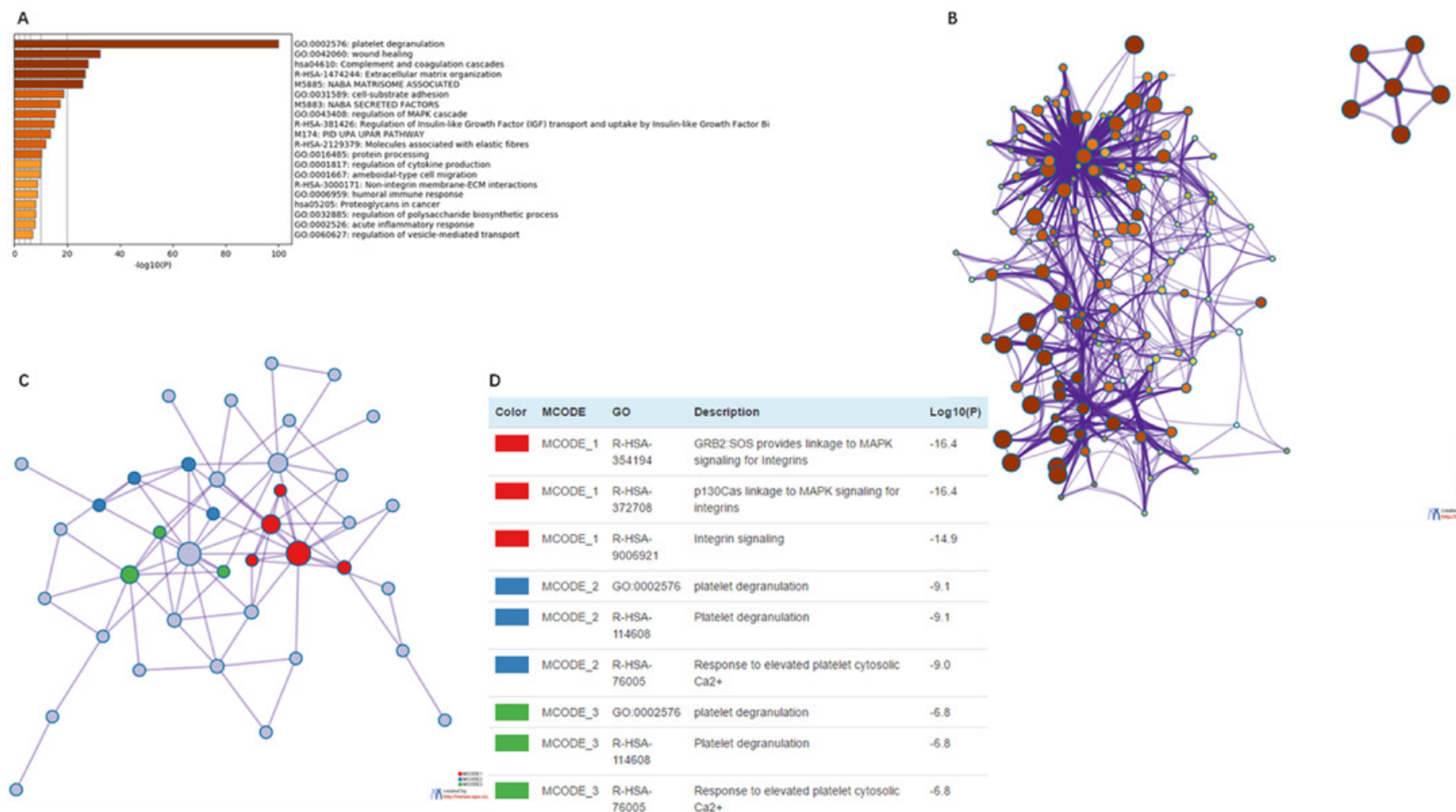

\section{D}

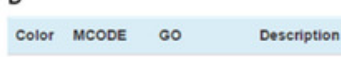

MCODE_1 R.HSA.

$\square$ MCODE_1 R.HSA.

GRB2 SOS provides inkage to MAPK signaling for integrins

P130Cas Inkage to MAPK signaling tor

integrins

MCODE_1 R.HSA.
9006921

Integrin signaling

MCOOE_2 GO-0002576 platelet degranulasion

MCODE_2 R.HSA.

Plastetet degranulation

Response to elevated platelet cytosolic

$\mathrm{Ca}$

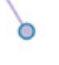

MCODE_2 R.HSA

platelet cegranulation

Platelet degranulation

Response
Ca2+ 
Figure 11

FIGURE 11. The mechanism of EMILINs in regulating LGG

A.The Venn diagram illustrated the 5 co-expressed

genes(PHTA2,CLCL1,FSTL1,IQGAP1,MYL12A) B-K.FSTL1and IQGAP1 were significantly associated with EMILINs.
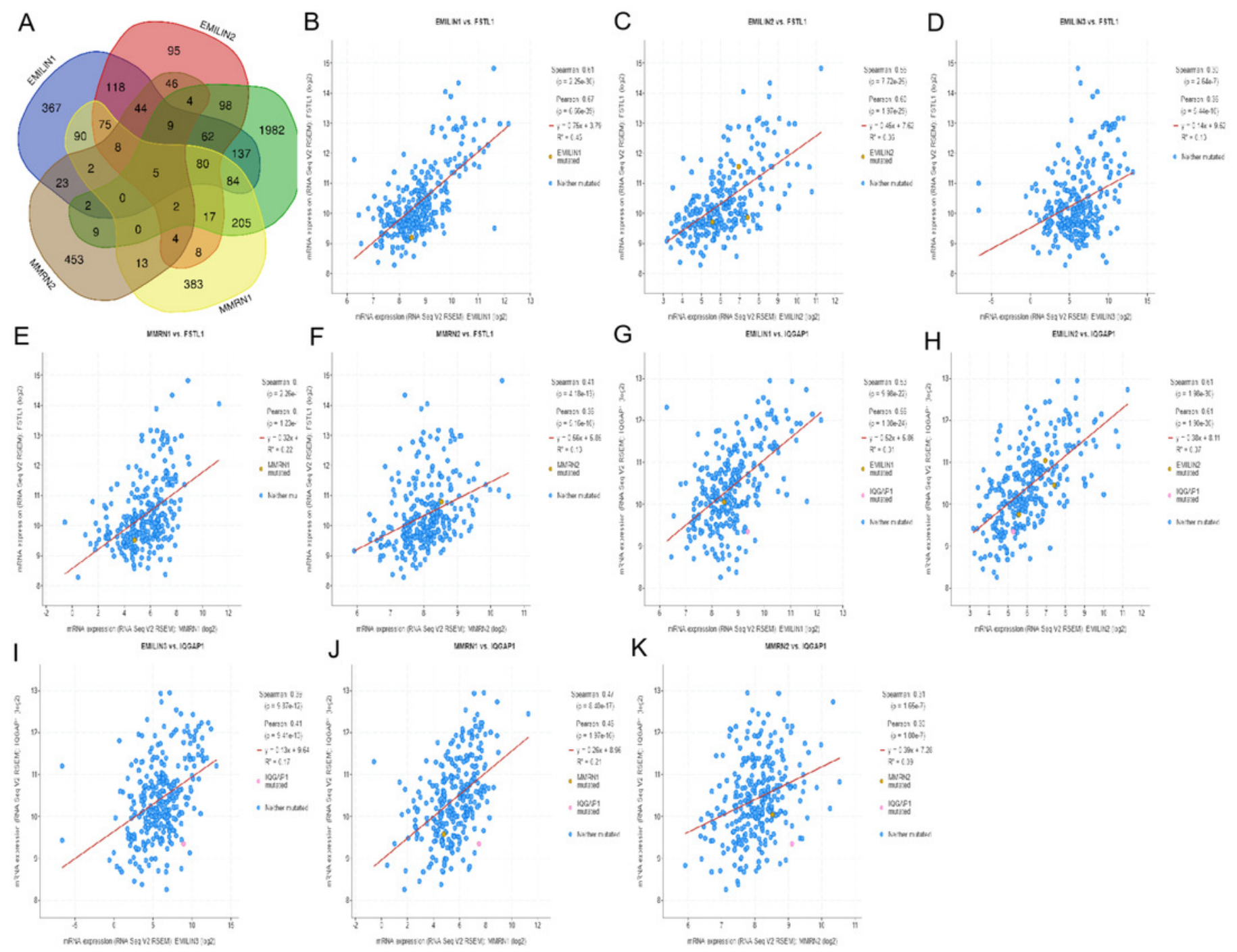

$\mathrm{K}$

unsas ocap

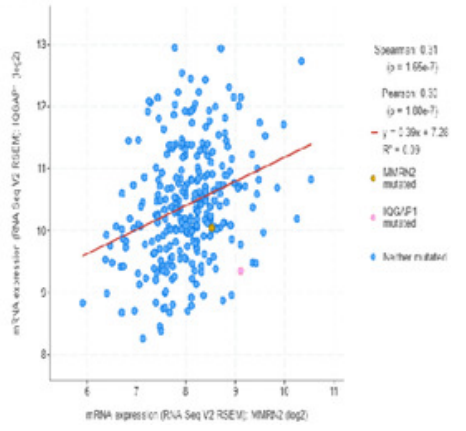


Figure 12

FIGURE 12. The mechanism of EMILINs in regulating LGG

A-J.CLIC1 and FSTL1 were significantly associated with EMILINs

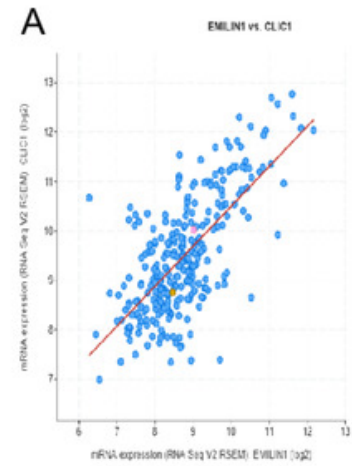

E
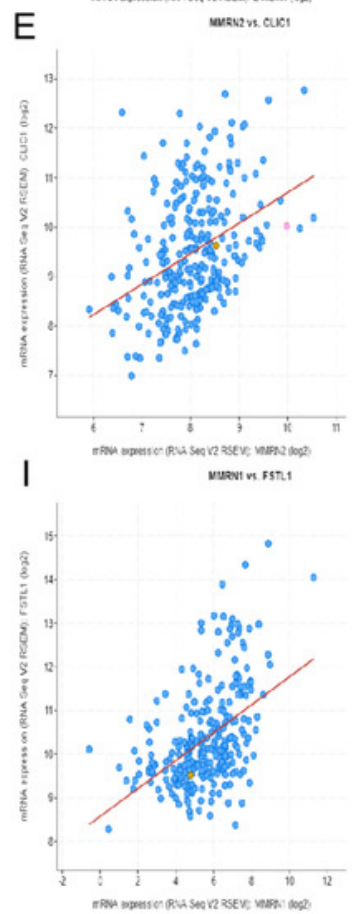
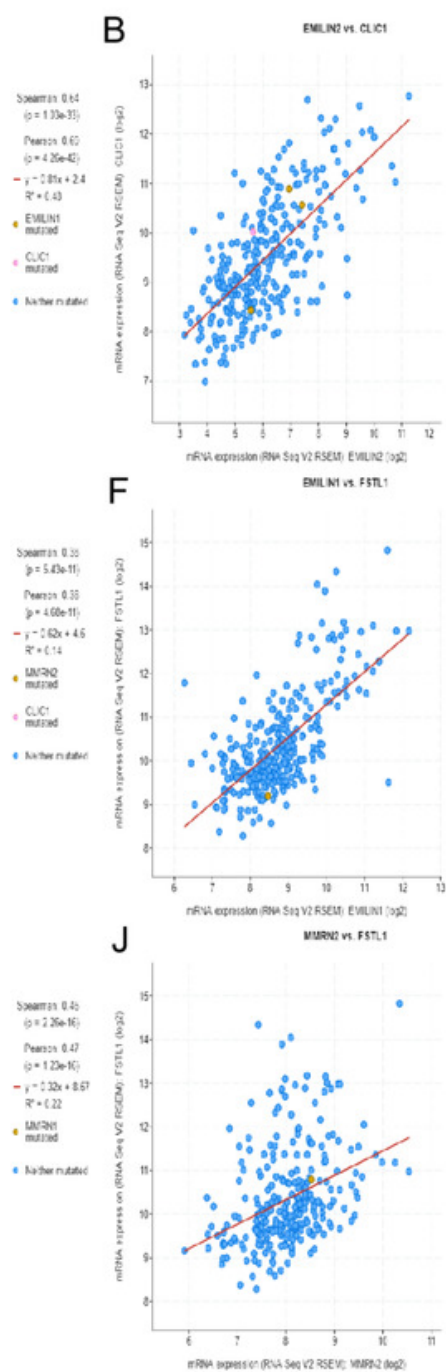

$\mathrm{F}$
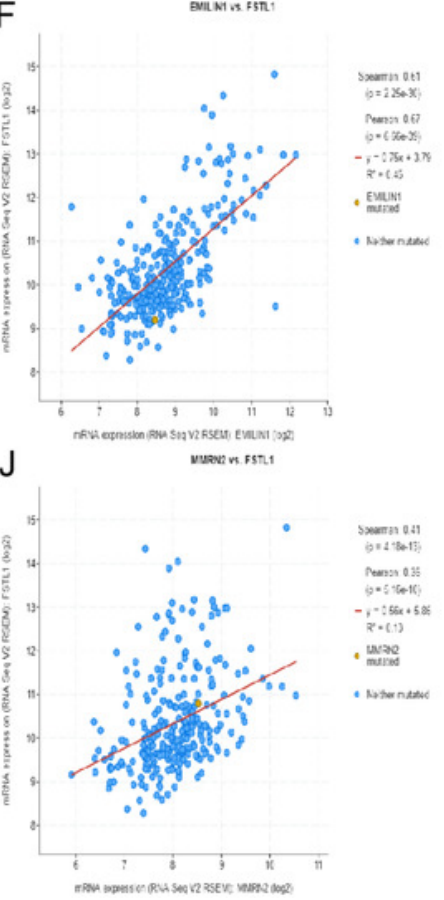

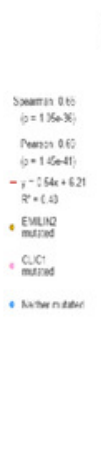

C

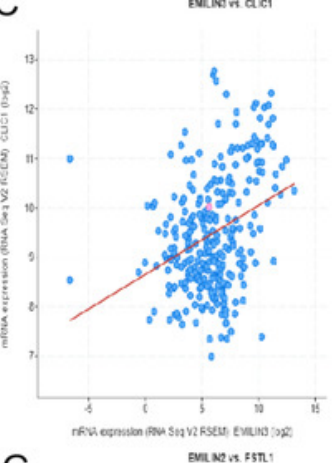

G

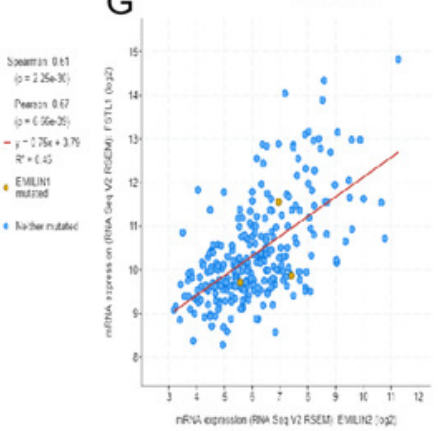

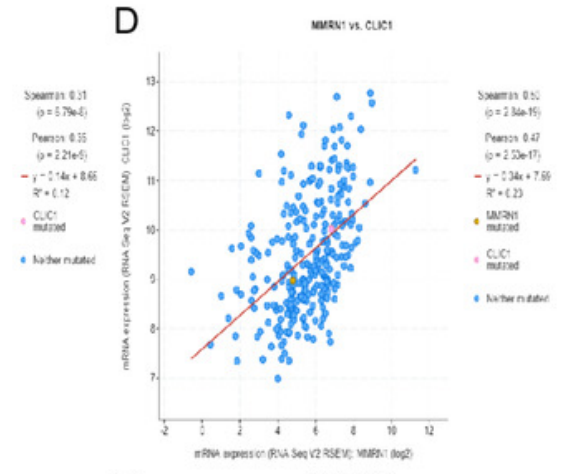

$\mathrm{H}$
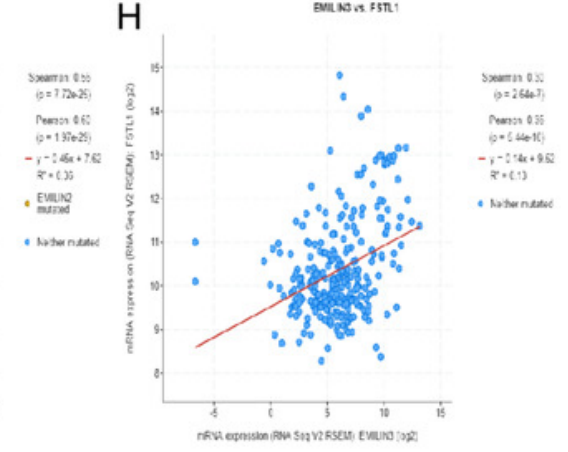
Figure 13

The mechanism of EMILINs in regulating LGG.

A-E.PHTA2 was significantly associated with EMILINs F-J.The prognostic value of 5 coexpressed genes in LGG patients.

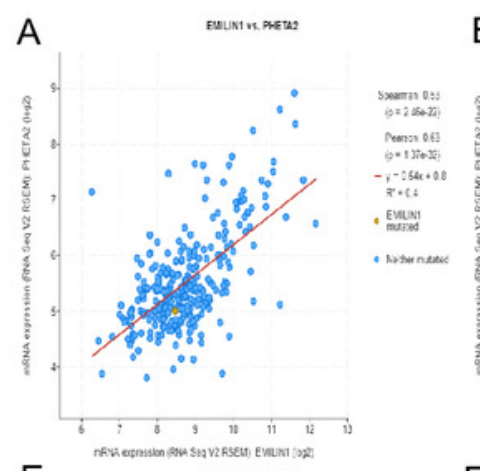

E
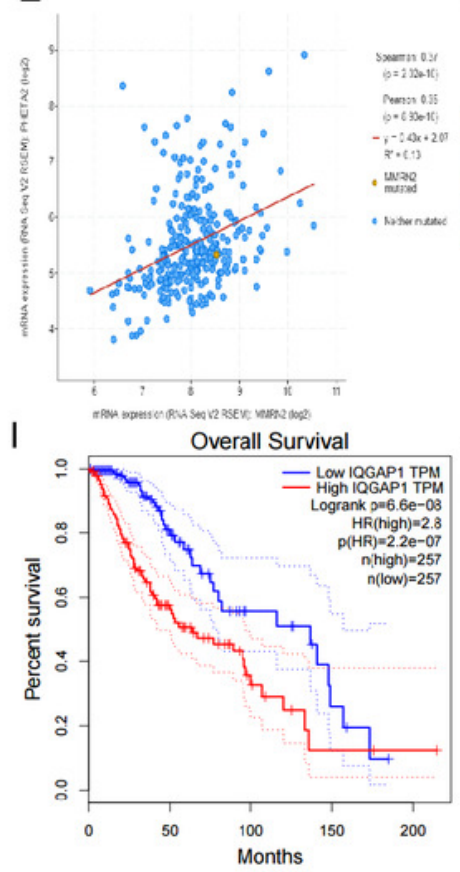

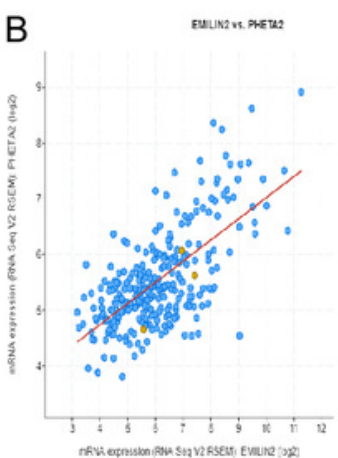

$\mathrm{F}$
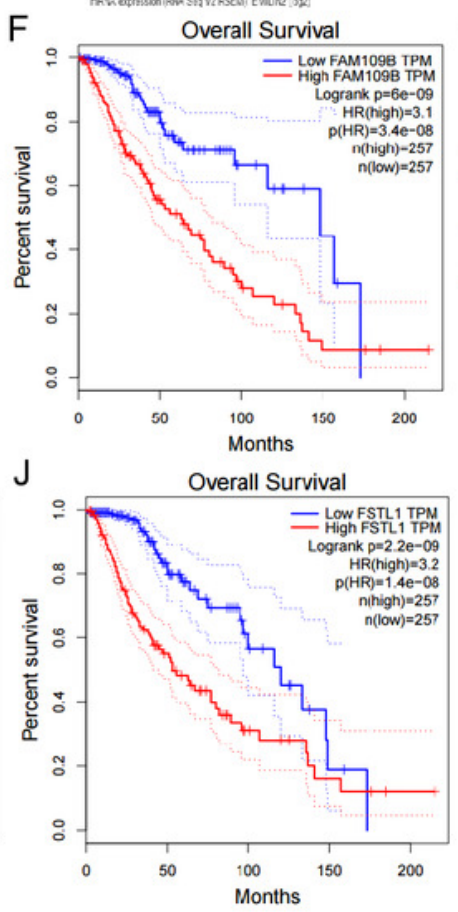

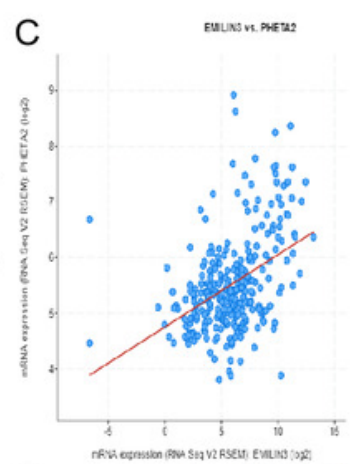

G

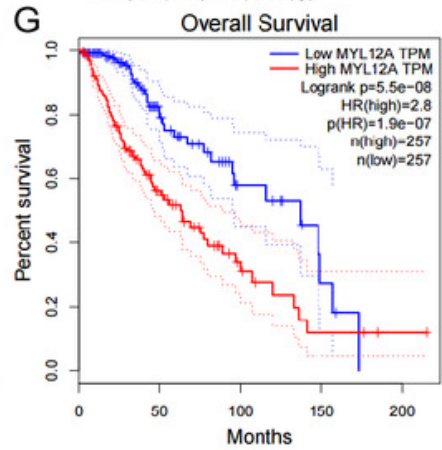

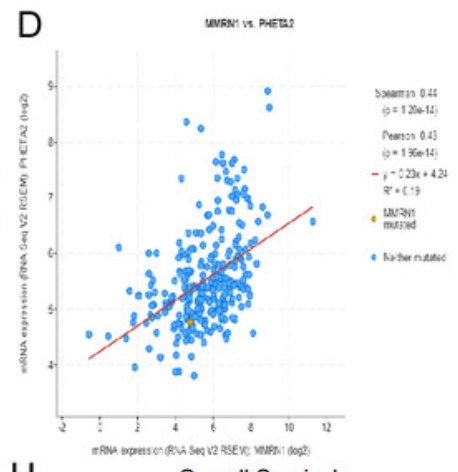

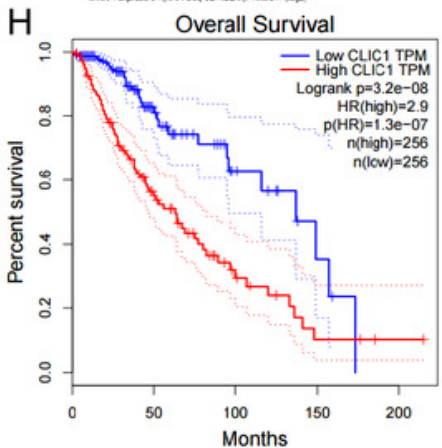




\section{Table $\mathbf{1}$ (on next page)}

The transcription levels of ENILIN/Multimerin family members in between different types of Brain and CNS Cancer and normal tissues (ONCOMINE) 
1 TABLE 1 The transcription levels of ENILIN/Multimerin family members in between different types of 2 Brain and CNS Cancer and normal tissues (ONCOMINE)

\begin{tabular}{|c|c|c|c|c|c|c|}
\hline & $\begin{array}{c}\text { Types of Brain and } \\
\text { CNS Cancer VS. } \\
\text { normal }\end{array}$ & $\begin{array}{l}\text { Fold } \\
\text { change }\end{array}$ & t-test & p-value & Ref & PMID \\
\hline \multirow[t]{7}{*}{ EMILIN1 } & $\begin{array}{c}\text { Glioblastoma vs. } \\
\text { Normal }\end{array}$ & 24.769 & 18.827 & $\begin{array}{c}2.04 E- \\
9\end{array}$ & Lee Brain & 16697959 \\
\hline & $\begin{array}{c}\text { Pilocytic } \\
\text { Astrocytoma vs. } \\
\text { Normal }\end{array}$ & 3.233 & 3.030 & 0.008 & $\begin{array}{l}\text { Gutmann } \\
\text { Brain }\end{array}$ & 11929829 \\
\hline & $\begin{array}{c}\text { Brain Glioblastoma } \\
\text { vs. Normal } \\
\text { Glioblastoma vs. } \\
\text { Normal }\end{array}$ & 6.401 & 11.066 & $\begin{array}{l}6.72 \mathrm{E}- \\
10 \\
8.00 \mathrm{E}- \\
11\end{array}$ & $\begin{array}{c}\text { TCGA } \\
\text { Brain } \\
\text { Sun Brain }\end{array}$ & \\
\hline & $\begin{array}{c}\text { Diffuse Astrocytoma } \\
\text { vs. Normal }\end{array}$ & 4.447 & 3.147 & 0.007 & Sun Brain & 16616334 \\
\hline & $\begin{array}{c}\text { Anaplastic } \\
\text { Oligodendroglioma } \\
\text { vs. Normal }\end{array}$ & 1.541 & 4.581 & $\begin{array}{l}4.82 E- \\
5\end{array}$ & $\begin{array}{c}\text { French } \\
\text { Brain }\end{array}$ & 16357140 \\
\hline & $\begin{array}{c}\text { Glioblastoma vs. } \\
\text { Normal }\end{array}$ & 1.974 & 7.018 & $\begin{array}{c}9.33 E- \\
5\end{array}$ & $\begin{array}{l}\text { Murat } \\
\text { Brain }\end{array}$ & 18565887 \\
\hline & $\begin{array}{c}\text { Glioblastoma vs. } \\
\text { Normal }\end{array}$ & 1.974 & 7.018 & $\begin{array}{c}9.33 E- \\
5\end{array}$ & $\begin{array}{l}\text { Murat } \\
\text { Brain }\end{array}$ & 18565887 \\
\hline \multirow[t]{2}{*}{ EMILIN2 } & $\begin{array}{c}\text { Glioblastoma vs. } \\
\text { Normal }\end{array}$ & 2.942 & 6.257 & $\begin{array}{c}1.50 \mathrm{E}- \\
4\end{array}$ & Lee Brain & 16697959 \\
\hline & $\begin{array}{c}\text { Glioblastoma vs. } \\
\text { Normal }\end{array}$ & 5.277 & 6.979 & $\begin{array}{c}2.68 E- \\
4\end{array}$ & $\begin{array}{l}\text { Bredel } \\
\text { Brain } 2\end{array}$ & 16204036 \\
\hline \multirow[t]{6}{*}{ EMILIN3 } & $\begin{array}{l}\text { Malignant Glioma, } \\
\text { NOS vs. Normal }\end{array}$ & 1.041 & 2.764 & 0.008 & $\begin{array}{c}\text { TCGA } \\
\text { Brain } 2\end{array}$ & \\
\hline & $\begin{array}{c}\text { Brain Glioblastoma } \\
\text { vs. Normal }\end{array}$ & 1.126 & 19.817 & $\begin{array}{c}1.68 E- \\
67\end{array}$ & $\begin{array}{c}\text { TCGA } \\
\text { Brain } 2\end{array}$ & \\
\hline & $\begin{array}{c}\text { Brain Astrocytoma } \\
\text { vs. Normal }\end{array}$ & 1.047 & 4.821 & $\begin{array}{l}4.80 \mathrm{E}- \\
6\end{array}$ & $\begin{array}{c}\text { TCGA } \\
\text { Brain } 2\end{array}$ & \\
\hline & $\begin{array}{c}\text { Glioblastoma vs. } \\
\text { Normal }\end{array}$ & 1.108 & 2.350 & 0.023 & $\begin{array}{l}\text { TCGA } \\
\text { Brain } 2\end{array}$ & \\
\hline & $\begin{array}{c}\text { Primary } \\
\text { Glioblastoma vs. } \\
\text { Normal }\end{array}$ & 1.051 & 4.394 & $\begin{array}{c}1.16 E- \\
5\end{array}$ & $\begin{array}{c}\text { TCGA } \\
\text { Brain } 2\end{array}$ & \\
\hline & $\begin{array}{c}\text { Anaplastic } \\
\text { Astrocytoma vs. } \\
\text { Normal }\end{array}$ & -1.027 & -1.884 & 0.046 & $\begin{array}{l}\text { Beroukhim } \\
\text { Brain }\end{array}$ & 18077431 \\
\hline
\end{tabular}




$\begin{array}{cccccc}\text { Anaplastic } & -1.389 & -4.489 & 0.001 & \text { Bredel } & 16204036 \\ \text { Oligoastrocytoma vs. } & & & & \text { Brain 2 } & \end{array}$

Normal

\begin{tabular}{cccccccc} 
MMRN1 & $\begin{array}{c}\text { Anaplastic } \\
\text { Oligodendroglioma }\end{array}$ & 1.089 & 2.368 & 0.027 & $\begin{array}{c}\text { Beroukhim } \\
\text { Brain }\end{array}$ & 18077431 \\
vs. Normal & & & & & \\
MMRN2 & $\begin{array}{c}\text { Glioblastoma vs. } \\
\text { Normal }\end{array}$ & 3.329 & 16.713 & $\begin{array}{c}7.77 E- \\
\text { Lee Brain }\end{array}$ & 16697959 \\
Primary & -1.215 & 10.058 & $\begin{array}{c}1.59 E- \\
\text { Beroukhim }\end{array}$ & 18077431 \\
Glioblastoma vs. & & & 17 & Brain & \\
Normal & & & & & \\
Secondary & -1.121 & -2.438 & 0.013 & Beroukhim & 18077431 \\
Glioblastoma vs. & & & & Brain & \\
Normal & & & & & \\
Glioblastoma vs. & -1.253 & -3.730 & 0.003 & TCGA & \\
Normal & & & & Brain 2 & \\
Brain Astrocytoma & -1.127 & -5.141 & $1.47 E-$ & TCGA & \\
vs. Normal & & & 6 & Brain 2 & \\
Brain Glioblastoma & -1.438 & -43.327 & $3.30 E-$ & TCGA & \\
vs. Normal & & & 185 & Brain 2 & \\
\hline
\end{tabular}

3 
Table 2 (on next page)

Table 2 Immune cell landscape compared with gene expression. 
Table 2 Immune cell landscape compared with gene expression

Tumor purity B cell CD8+ T cell CD4+ T cell Macrophage Neutrophil Dendritic

cell

\begin{tabular}{lcccccccc}
\hline & $\mathrm{r}$ & $\mathrm{r}$ & $\mathrm{r}$ & $\mathrm{r}$ & $\mathrm{r}$ & $\mathrm{r}$ & $\mathrm{r}$ \\
EMILIN1 & $(-)$ & $(+)$ & $(-)$ & $(++)$ & $(++)$ & $(++)$ & $(++)$ \\
EMILIN2 & $(-)$ & $(++)$ & $(+)$ & $(++)$ & $(++)$ & $(++)$ & $(++)$ \\
EMILIN3 & $(-)$ & $(+)$ & $(+)$ & $(+)$ & $(+)$ & $(++)$ & $(+)$ \\
MMRN1 & $(-)$ & $(++)$ & $(+)$ & $(++)$ & $(++)$ & $(+++)$ & $(+++)$ \\
MMRN2 & $(+)$ & $(+)$ & $(+)$ & $(+)$ & $(+)$ & $(+)$ & $(+)$ \\
\hline
\end{tabular}

1 Categorized Pearson's product-moment correlation of immune cell landscape of LGG compared

2 with TCGA gene expression of EMILIN1,EMILIN2,EMILIN,MMRN1,MMRN2 (TIMER).r,

3 categorized Pearson's correlation coefficient;(---), -1.0 to -0.5 , strong negative association; (--),

$4-0.5$ to -0.3 , weak negative association; $(-),-0.3$ to 0.1 , little association. $(+),+0.1$ to 0.3 , little

5 association; $(++)+0.3$ to +0.5 , weak positive association; $(+++)$, +0.5 to +1.0 , strong positive

6 association. 


\section{Table 3(on next page)}

Table3. The function enrichment analysis of EMILIN/Multimerin family members and neighbor genes in LGG (Metascape). 
1 Table3. The function enrichment analysis of EMILIN/Multimerin family members and neighbor 2 genes in LGG (Metascape)

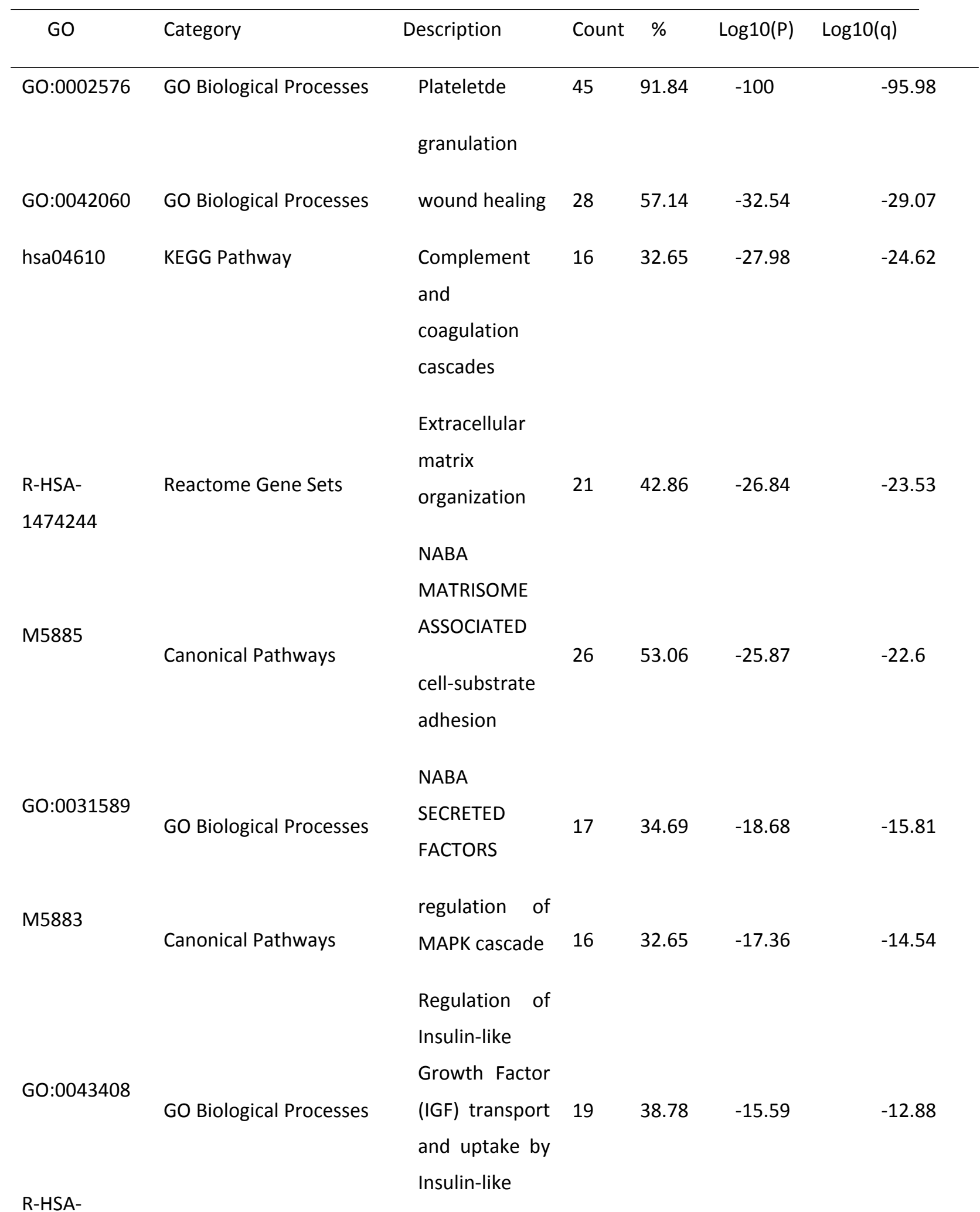




\begin{tabular}{|c|c|c|c|c|c|c|}
\hline \multirow[t]{7}{*}{381426} & Reactome Gene Sets & Growth Factor & 11 & 22.45 & -14.95 & -12.3 \\
\hline & & $\mathrm{Bi}$ & & & & \\
\hline & & PID UPA UPAR & & & & \\
\hline & & PATHWAY & & & & \\
\hline & & Molecules & & & & \\
\hline & & associated & & & & \\
\hline & & with & & & & \\
\hline \multirow{4}{*}{ M174 } & & & & & & \\
\hline & & elastic fibres & & & & \\
\hline & Canonical Pathways & & 8 & 16.33 & -13.75 & -11.19 \\
\hline & & protein & & & & \\
\hline RS-HSA- & & processing & & & & \\
\hline 2129379 & Reactome Gene Sets & Drotonaluranc & 7 & 14.29 & -11.96 & -9.53 \\
\hline GO:0016485 & & in cancer & & & & \\
\hline \multirow[t]{3}{*}{ GO:0001817 } & & regulation of & & & & \\
\hline & GO Biological Processes & polysaccharide & 11 & 22.45 & -10.3 & -7.96 \\
\hline & GO Biological Processes & $\begin{array}{l}\text { biosynthetic } \\
\text { process }\end{array}$ & 14 & 28.57 & -10 & -7.69 \\
\hline GO:0001667 & & regulation of & & & & \\
\hline R-HSA- & & cytokine & & & & \\
\hline 3000171 & GO Biological Processes & production & 12 & 24.49 & -9.91 & -7.61 \\
\hline \multirow{2}{*}{ GO:0006959 } & Reactome Gene Sets & acute & 6 & 12.24 & -8.68 & -6.5 \\
\hline & & inflammatory & & & & \\
\hline \multirow[t]{2}{*}{ hsa05205 } & & response & & & & \\
\hline & GO Biological Processes & regulation of & 10 & 20.41 & -8.65 & -6.49 \\
\hline \multirow{4}{*}{ GO:0032885 } & KEGG Pathway & vesicle- & 8 & 16.33 & -8.14 & -6.03 \\
\hline & & mediated & & & & \\
\hline & & transport & & & & \\
\hline & GO Biological Processes & & 5 & 10.2 & -7.94 & -5.86 \\
\hline
\end{tabular}


GO:0002526

GO Biological Processes

GO:0060627

GO Biological Processes
8

16.33

$-7.82$

$-5.76$

10

20.41

$-7.01$

$-5.01$

3 